\title{
The impact of liquidity crises on cash flow sensitivities
}

\author{
Wolfgang Drobetz ${ }^{\mathrm{a}}$, Rebekka Haller ${ }^{\mathrm{a}}$, Iwan Meier ${ }^{\mathrm{b}}$, Vefa Tarhan ${ }^{\mathrm{c}, \mathrm{d}, *}$ \\ a Faculty of Business, Hamburg University, Moorweidenstraße 18, 20148 Hamburg, Germany \\ ${ }^{\mathrm{b}}$ HEC Montréal, 3000, chemin de la Côte-Sainte-Catherine, Montréal (Québec) H3T 2A7, Canada \\ ' Quinlan School of Business, Loyola University, 820 N. Michigan Avenue, Chicago, IL 60611, USA \\ ${ }^{\mathrm{d}}$ Bilkent University, Ankara, Turkey
}

\section{A R T I C L E I N F O}

\section{Article history:}

Received 1 June 2016

Received in revised form 9 February 2017

Accepted 6 March 2017

Available online 20 March 2017

\section{JEL classification:}

G01

G31

G32

Keywords:

Cash flow sensitivity

Financial constraints

Liquidity crises

Investment spending

Supply side shock

\begin{abstract}
A B S T R A C T
We examine the relationship between liquidity crises and frictions in raising funds, and find that both the gap between the cash flow sensitivities of financially healthy and weak firms and the cash flow sensitivities of healthy and weak firms themselves are positively correlated with the severity of liquidity crises. Using a multi-equation model of cash flow sensitivities, we find that moderate liquidity crises mostly affect firms' financing activities. The recent financial crisis was especially severe for financially weak firms and curtailed both their investment and financing decisions. Financially healthy firms were able to protect their investments by maintaining financial flexibility.
\end{abstract}

(C) 2017 Board of Trustees of the University of Illinois. Published by Elsevier Inc. All rights reserved.

\section{Introduction}

In their seminal study, Fazzari, Hubbard, and Petersen (1988) use investment-cash flow sensitivities to show that financially weak firms experience more difficulty raising external funds than financially healthy firms. ${ }^{1}$ They interpret this as evidence that financially weak firms face frictions in accessing capital markets. We refer to this approach for detecting capital market constraints as the "traditional" test. All subsequent studies essentially use Fazzari et al. 's (1988) single-equation model, which regresses capital expenditures on cash flows (along with some control variables). A statistically significant and positive coefficient on cash flow is interpreted as evidence of constrained access to capital markets. The single-equation approach posits that, if a firm cuts its invest-

\footnotetext{
* Corresponding author at: Quinlan School of Business, Loyola University, $820 \mathrm{~N}$. Michigan Avenue, Chicago, IL 60611, USA.

E-mail address: vtarhan@luc.edu (V. Tarhan).

1 In this study, we use the terms "financially weak" and "financially healthy" rather than "constrained" and "unconstrained," which are used in the earlier literature. This is because "constraint" would then be used in three different contexts, which we believe is overly confusing: (1) as above, to denote a firm's overall health, (2) to denote the level of access to capital markets, and (3) the sense that we also estimate our model subject to some constraints.
}

ments in response to a cash flow shortfall, it must be because it is unable to raise sufficient external funds to compensate for the shortfall, and is thus financially constrained.

Our primary aim in this article is to examine whether firms' constraints in accessing capital markets vary with the macroeconomic environment. In particular, we expect liquidity crises to have adverse effects on firms' abilities to raise funds. Against the backdrop that previous studies used pooled data that covered different liquidity environments, we make several contributions to the literature on capital market access constraints.

First, because pooled data may mask differences in how firms behave under different liquidity-related economic states, we estimate our model separately during non-crisis periods, during the relatively moderate liquidity crises prior to 2007, and during the recent 2007-2009 financial crisis (or subprime mortgage crisis). We then explore whether the traditional measure of capital market frictions - the cash flow sensitivity differences between financially weak and healthy firms - increases with the severity of liquidity crises.

Second, to get a complete understanding of the correlation between liquidity conditions and the size of the hurdles firms face in raising funds, we estimate cash flow sensitivities separately during non-crisis and liquidity crisis periods, and then compare the two sets of estimates to assess whether capital market frictions increase 
with the severity of liquidity crises. We hypothesize that financially weak firms will be affected more than healthy firms during liquidity crises, and evaluate the differences in cash flow sensitivities between non-crisis and liquidity crisis periods separately for financially weak and healthy firms. These extensions of the traditional test enable us to assess how crisis severity impacts the constraints in accessing capital markets.

Third, capital market frictions impose costs on firms by creating distortions in their financial decisions, e.g., in the form of underinvestment problems. $^{2}$ The traditional metric for detecting capital market constraints only indicates to what extent weak firms operate suboptimally relative to healthy firms. If the cash flow sensitivities of both financially weak and healthy firms increase during liquidity crises, but the gap between the cash flow sensitivities remains the same, the traditional measure for financial constraints indicates no change in frictions. In contrast, we interpret the sum of the changes in the cash flow sensitivities from normal times to crisis periods faced by financially weak and healthy firms as the total costs of liquidity crises for the economy.

Fourth, both survey (Campello, Graham, \& Harvey, 2010; Campello, Giambona, Graham, \& Harvey, 2011) and empirical studies (Duchin, Ozbas, \& Sensoy, 2010; Ivashina \& Scharfstein, 2010; Almeida, Campello, Laranjeira, \& Weisbenner, 2011; Bliss, Cheng, \& Denis, 2013) show evidence that the subprime mortgage crisis was unusually severe. If cash flow sensitivities are a legitimate measure of the severity of liquidity crises, they should reflect firms' increased difficulties in raising funds via debt and equity offerings during the recent financial crisis. Having this crisis in our sample offers an ideal case for testing whether it was unusually severe in terms of measures of capital market access constraints.

Finally, while almost all prior studies in the literature use Fazzari et al. 's (1988) single-equation model, we implement the multiequation cash flow sensitivity model of Gatchev, Pulvino, and Tarhan (2010). During a severe crisis, adverse effects are unlikely to be confined to firms' investment decisions. They may also affect their financing and shareholder distribution decisions. Since the Gatchev et al. (2010) model includes all the important investment, financing, and shareholder payout variables, we can provide a comprehensive description of how firms particularly coped with the recent financial crisis.

A large strand of literature that follows Fazzari et al.'s (1988) approach has confirmed their findings, and concurs that financially weak firms exhibit higher investment-cash flow sensitivities than healthy firms (Gilchrist \& Himmelberg, 1995; Allayannis \& Mozumdar, 2004; among others). However, other studies find evidence to the contrary, and show a non-monotonic relationship between investment cash flow sensitivities and financial constraints (Kaplan \& Zingales, 1997; Kadapakkam, Kumar, \& Riddick, 1998; Cleary, 1999). ${ }^{3}$ One explanation for these conflicting results may be that the presence and extent of financial constraints are not directly observable (Moyen, 2004; Becchetti, Castelli, \& Hasan,

\footnotetext{
2 If firms are unable to fully offset decreases in cash flows by approaching capital markets (or by drawing down their cash balances), then not only are their investment activities likely to become suboptimal, but their operating, financing, and shareholder distribution activities may as well. For the sake of simplicity, most of our discussions focus on the underinvestment problem as an example of the distortions caused by capital market frictions.

3 Moyen (2004) posits that debt financing may explain the non-monotonic relationship between investment-cash flow sensitivities and financial constraints. The effect of debt financing on investments is not captured by the single-equation model, thus it magnifies the investment-cash flow sensitivity of healthy firms. Other studies focus on firms with low or even negative cash flows and operating losses (Allayannis \& Mozumdar, 2004; Bhagat, Moyen, \& Suh, 2005; Cleary, Povel, \& Raith, 2007) or lifecycle effects (Hovakimian, 2009). International evidence of investment-cash flow sensitivities is shown in Love (2003), Lins, Strickland, and Zenner (2005), and Francis, Hasan, Song, and Waisman (2013).
}

2010). Different studies use different proxies for financial constraints, and potentially estimate cash flow sensitivities differently. Another possible explanation is that Tobin's $q$ may be estimated with error, implying that investments are sensitive to cash flows because cash flows reflect growth opportunities rather than financial constraints (Erickson \& Whited, 2000; Roberts \& Whited, 2012).

Brown and Petersen (2009) extend the single-equation framework along two dimensions. First, they assume adjustment costs in investments, and include lagged investments in their model. Second, they add a variable that captures the amount of firms' external financing. ${ }^{4}$ Bond and Söderbom (2013) use simulated data to show that in a constrained regime the sensitivity of investment to cash flow conditional on measures of Tobin's $q$ increases monotonically with the cost for external financing. McLean and Zhao (2014) find that the investment-cash flow sensitivity declines when economic conditions improve (and external finance is less costly). They directly test the relationship between cash flows and financing variables, and find that debt and equity offering sensitivities to cash flows become more pronounced as economic conditions improve.

Our main results are as follows: first, in terms of the traditional metric, we find that firms do not face frictions in raising funds during normal times. However, even during the relatively moderate crisis periods prior to 2007, we find evidence that capital market frictions in the traditional sense exist. These frictions are detected in firms' financing decisions. In contrast, during the recent financial crisis of 2007-2009, frictions are detected in both the financingand investment-cash flow sensitivities of financially weak firms.

Second, we detect the presence of capital market constraints in the financing-cash flow sensitivities of financially weak firms even during moderate crises. This evidence is stronger during the recent financial crisis, when we again find capital market access constraints in both investment- and financing-cash flow sensitivities of financially weak firms. The capital budgets of these firms were curtailed sharply during the subprime mortgage crisis: the size of the investment-cash flow sensitivity estimate is $\$ 0.554$ for a $\$ 1$ decline in cash flows (the highest estimate for the other subsamples is only \$0.041). This finding confirms that the recent financial crisis was an unusually severe liquidity crisis.

Third, we show evidence that capital market frictions of financially healthy firms are primarily confined to their financing-cash flow sensitivities. These firms were able to insulate their capital expenditures from the effects of the pre-2007 liquidity crises. Even during the recent financial crisis, they were able to protect $96 \%$ of their capital expenditures. It seems that the key to protecting investments is having financial flexibility in terms of unused short-term borrowing capacity and sufficient excess cash. However, although these firms are considered financially healthy, they were unable to issue long-term debt during the recent financial crisis, which supports the widely asserted observation that the capital markets "froze."

Finally, with the exception of financially weak firms during the recent financial crisis, the frictions in raising funds are not observed in the investment-cash flow sensitivities that the literature has focused on. Instead, we detect them in the cash flow sensitivities of the financing variables, primarily in the leverage variables (shortand long-term borrowings and reduction in cash holdings). Overall, we conclude that there is a strong and positive correlation between the difficulties firms face in raising funds and the presence and severity of liquidity crises.

\footnotetext{
4 Dasgupta, Noe, and Wang (2011) investigate the allocation of cash flows to alternative uses based on the cash flow identity. They find that firms' behavior is consistent with the pecking order hypothesis of Myers and Majluf (1984). In particular, firms use a $\$ 1$ cash inflow to add to cash balances and reduce external financing rather than paying out dividends or substantially increasing investments.
} 
The remainder of the paper is structured as follows: Section 2 describes our methodology and presents the data. Section 3 presents the results of our tests for the time variation of investment and financing cash flow sensitivities, conditional on firms' financial health. Section 4 documents the correlation between aggregate (economy-wide) capital market access constraints and the severity of liquidity crises. Section 5 concludes.

\section{Methodology and data}

\subsection{Traditional model of investment-cash flow sensitivities}

Fazzari et al. (1988) propose a single-equation model to determine whether firms face constraints in accessing capital markets. In their specification, the capital expenditures variable is regressed on cash flows (both divided by beginning-of-period capital stock) and on Tobin's $q$, which controls for firms' investment opportunities. We replicate the traditional single-equation framework by estimating the following model:

$$
\frac{\text { CAPX }_{i, t}}{P P E N T_{i, t-1}}=a_{t}+a_{i}+b_{1} \times Q_{i, t-1}+b_{2} \times \frac{C F L_{i, t}}{P P E N T_{i, t-1}}+\varepsilon_{i, t},
$$

where CAPX is capital expenditures, PPENT is net property, plant, and equipment, $Q$ is Tobin's $q$, and CFL is cash flows. The intercept terms $a_{t}$ and $a_{i}$ control for time and firm fixed effects, respectively. ${ }^{5}$ The coefficient $b_{2}$ on cash flows is the estimate of the investmentcash flow sensitivity. A positive and high estimate for this variable indicates that firms are forced to reduce capital expenditures in response to cash flow shortfalls. The implication in the literature is that these firms are unable to raise sufficient external funds to offset cash flow shortfalls.

\subsection{Gatchev et al.'s (2010) system of equations model}

Gatchev et al. (2010) suggest that static single-equation models suffer from an omitted variables problem, especially in the case of variables with inertia. Supporting their conjecture, we find that capital expenditures, asset sales, share repurchases, and dividends exhibit the highest inertia. Adjustment costs of stopping and restarting investments in fixed assets and the fact that firms have annual replacement projects may explain this inertia in capital expenditures (intertemporal dependence of financial decisions). In contrast, financing variables do not exhibit very strong inertia because adjustment costs are lower. It is surprising that earlier studies focus on capital expenditures, the variable with the highest degree of persistence that likely suffers from the omitted variables problem the most. $^{6}$

Gatchev et al. (2010) also argue that firms may respond to cash flow shortfalls by adjusting other variables besides investments. Single-equation models do not acknowledge that sources of funds equal uses of funds for all firms and at all times (interdependence of financial decisions). Ignoring the sources-equal-uses identity produces inefficient coefficient estimates. Conclusions about the presence or absence of capital market frictions are reached on the basis of differences in estimated coefficients across subsamples.

\footnotetext{
5 The variable constructions with the Compustat items are detailed in Appendix A in Table A1.

${ }^{6}$ Our results strongly confirm this argument. The vector $\boldsymbol{K}$ in Eq. (3) below contains the corresponding coefficients for lagged model variables. In results not reported, we find that the estimates for lagged capital expenditures, asset sales, share repurchases, and dividends exhibit the highest inertia, with lagged coefficients of $0.969,0.848,0.706$, and 0.591 , respectively, for the full 1972-2011 sample period. In contrast, the estimates for lagged long- and short-term borrowing as well as for internal borrowing (i.e., use of cash balances) from our model exhibit no inertia (estimates of $0.059,0.058$, and 0.018 , respectively).
}

Therefore, precision of the estimates is important in this literature. The interdependence problem may also be responsible for misclassifying firms as "unconstrained" when they are effectively "constrained" (and vice versa). ${ }^{7}$

Following Gatchev et al.'s (2010) methodology, we estimate a system of nine equations subject to the sources-equal-uses constraint. The following accounting identity always holds ex post:

$$
\begin{aligned}
& \text { CAPX }_{t}+\text { ACQUIS }_{t}-\text { ASALES }_{t}+R P_{t}+\text { DIV }_{t}-\text { EQUISS }_{t}-\Delta \text { LTD }_{t} \\
& -\Delta \text { STD }_{t}+\Delta \mathrm{CASH}_{t} \equiv \mathrm{CF}_{t},
\end{aligned}
$$

where CAPX is capital expenditures, ACQUIS is acquisitions, ASALE is asset sales, $R P$ is share repurchases, DIV is dividends, EQUISS is equity issues, and $\triangle C A S H$ is changes in cash balances from year $t-1$ to year $t$. $\triangle L T D$ and $\triangle S T D$ are long- and short-term debt issues, respectively, and $C F$ is cash flows. All variables in Eq. (2) are assumed to be endogenous, except $C F$. Table A1 in Appendix A gives the definitions we use in constructing these variables.

In estimating our system of equations model, we control for firms' investment opportunities by using the market-to-book ratio of equity $(M B)$. We include firm size (SIZE), measured by the logarithm of the book value of total assets, to account for the possibility that larger firms have easier access to external capital. We estimate the following system of nine equations, subject to the constraints in Eq. (3) below ${ }^{8}$ :

$$
\begin{aligned}
& {\left[\begin{array}{l}
- \text { CAPX }_{t} \\
- \text { ACQUIS }_{t} \\
\text { ASALES }_{t} \\
-R P_{t} \\
-D_{t} \\
\text { EQUISS }_{t} \\
\Delta \text { LTD }_{t} \\
\Delta S T D_{t} \\
- \text { CASH }_{t}
\end{array}\right]=\boldsymbol{L}\left[C F_{t}\right]+\boldsymbol{K}\left[\begin{array}{l}
- \text { CAPX }_{t-1} \\
- \text { ACQUIS }_{t-1} \\
\text { ASALES }_{t-1} \\
-R P_{t-1} \\
-D I V_{t-1} \\
\text { EQUISS }_{t-1} \\
\Delta L T D_{t-1} \\
\Delta S T D_{t-1} \\
-\Delta \text { CASH }_{t-1}
\end{array}\right]} \\
& +\boldsymbol{M}\left[\begin{array}{l}
M B_{t} \\
S I Z E_{t}
\end{array}\right]+\left[\begin{array}{l}
-e_{\text {CAPX }, t} \\
-e_{A C Q U I S, t} \\
e_{A S A L E S, t} \\
-e_{R P, t} \\
-e_{D I V, t} \\
e_{E Q U I S S, t} \\
e_{\Delta L T D, t} \\
e_{\Delta S T D, t} \\
-e_{\Delta C A S H, t}
\end{array}\right],
\end{aligned}
$$

\footnotetext{
${ }^{7}$ For example, if financially weak firms are not able to access capital markets, they may protect their capital expenditures by selling assets. In fact, survey evidence in Campello et al. (2011) shows that most financially weak firms funded their ongoing operations by selling assets during the recent financial crisis (in addition to deep cuts in capital expenditures). This effect weakens the correlation between cash flows and capital expenditures, and therefore these firms appear less constrained.

8 The system of equations in Eq. (3) and the constraints in Eq. (4) are derived from a model where managers minimize adjustment costs. Adjustment costs increase with how far the decision variables deviate from their target levels. Moreover, the faster is the move to the desired target level, the higher are the adjustment costs. See Gatchev et al. (2010) and Spindt and Tarhan (1980) for the derivation of the model.
} 
where $e_{C A P X}, \ldots, e_{\triangle C A S H}$ are the error terms associated with the nine financing, investment, and payout variables. In Eq. (3), the use variables are capital expenditures, acquisitions, share repurchases, dividends, and changes in cash holdings. ${ }^{9}$ We estimate Eq. (3) subject to the sources-equal-uses identity of Eq. (2), which implies imposing the following set of constraints for the parameter matrices:

$$
\boldsymbol{i}^{\prime} \mathbf{L}=-1, \quad \boldsymbol{i}^{\prime} \boldsymbol{K}=\mathbf{0}_{1 \times 9}, \quad \boldsymbol{i}^{\prime} \boldsymbol{M}=\mathbf{0}_{1 \times 2} .
$$

The first restriction in Eq. (4) states that, when there is a shock in cash flows, the sum of the estimates for sources and uses variables will add up to $\$ 1$, and will have the opposite sign of the change in cash flows. If, for example, the source variable $C F$ increases by $\$ 1$, then either (1) the other source variables must decline by $\$ 1$, (2) the use variables must increase by $\$ 1$, or (3) the response of some combination of source and use variables must sum to $\$ 1$. If the shock originates from the exogenous controls (MB and SIZE) or from any lagged dependent variable, the total response across equations must sum to zero (second and third set of restrictions in Eq. (4)) as these variables do not represent either sources or uses of funds in the current period. ${ }^{10}$

\subsection{Identifying the liquidity crises}

We divide our sample years into liquidity crisis and nonliquidity crisis periods to examine financing constraints under different liquidity-related regimes. As per Reinhart and Rogoff (2011), we identify the three pre-2007 liquidity crises as follows: (1) the oil crisis of 1975, (2) the savings and loan crisis of 1984-1991, and (3) the information technology bubble and energy crisis of 2002-2003. ${ }^{11}$ In contrast to the relatively moderate liquidity crises, the financial system suffered much more pronounced adverse liquidity conditions during the most recent crisis, when bank, bond, and equity financing sources were simultaneously affected (Gorton \& Metrick, 2012; Duca, 2013).

Several studies maintain that the recent financial crisis (subprime mortgage crisis) encompassed 2007 through 2009 (Campello et al., 2010; Duchin et al., 2010; Almeida et al., 2011; Kahle \& Stulz, 2013). We also use this time period to date the crisis. Our analysis uses annual data even if a crisis begins and ends during the course of a year. Therefore, we assume that its effects are reflected, at least partially, in end-of-year data. From 2010 onward, firms had record levels of profits and cash holdings (Sanchez \& Yurdagul, 2013), and the Federal Reserve continued its accommodative monetary policy with extremely low interest rates. Therefore, the reason behind the lack of corporate investments was not high costs or scarce availability of funds, but rather a demand shock caused by firms' perceptions that global uncertainties were exceedingly high (Mian \& Sufi, 2014). ${ }^{12}$

\footnotetext{
${ }^{9}$ We can consider asset sales as a negative use variable or as a source variable. In both cases, its expected sign is negative, which indicates that a decline in cash flows is expected to trigger asset sales.

10 The sources-equal-uses constraint in Eq. (4) can either be directly in the data, or imposed when estimating the system. Chang, Dasgupta, Wong, and Yao (2014) differentiate between what they refer to as "explicit constraints" (as used in Gatchev et al., 2010) and "implicit constraints," i.e., where the data is constructed to satisfy the sources-equal-uses identity.

11 See Carmen Reinhart's webpage: http://www.carmenreinhart.com/data/ browse-by-topic/topics/7/.

12 In their third quarter 2012 Duke University CFO Business Outlook survey, Graham and Harvey (2012) show that $97 \%$ of responding CFOs indicated that a 50 -basis point reduction in borrowing costs would not cause them to initiate, accelerate, or increase their investments. Even for a one-percentage-point reduction, which is substantial given the already very low interest rates, over $91 \%$ of the participants responded in the same manner. When the question was repeated for a two-percentage-point reduction, $84 \%$ of the respondents gave the same answer.
}

\subsection{Data}

Our analysis uses listed U.S. firms from Compustat North America over the 1971-2011 period. We report our results for the 1972-2011 sample period because the model in Eq. (3) uses one-year lagged variables. The sample includes all firms with consolidated balance sheet data and positive values for total book and market values of assets. As in Gatchev et al. (2010), we exclude financial firms (SIC codes 6000-6999) and regulated utilities (SIC codes 4900-4999). Table A1 summarizes the definitions and Compustat codes of the source, use, and control variables that enter our multi-equation model. Following Gatchev et al. (2010), we replace missing values with zero. Finally, we trim the market-to-book ratio at the $95 \%$ tail. The final full sample consists of 217,900 firm-year observations.

Table 1 shows the means and standard deviations for all variables in our model as a proportion of total assets (except for firm size and market-to-book ratio). Panel A reports descriptive statistics for the full sample; Panels $B$ and $C$ further subdivide the sample according to firms' financial health. All panels show descriptive statistics for the full sample period, the non-crisis years of 1972-2007 and 2010-2011, the three liquidity crisis periods prior to 2007, and the recent financial crisis of 2007-2009. Panel A indicates that the mean cash flows during the full sample period is slightly negative but not significantly different from zero. However, cash flows decline as the liquidity conditions in the economy become more severe. While average annual cash flows are $-0.1 \%$ during normal times, they sharply decrease to $-5.4 \%$ during the recent financial crisis. Average annual short- and long-term borrowings, as well as changes in cash holdings, also decline during the recent financial crisis period relative to non-crisis years. Capital expenditures are around $6.5 \%$ of total assets during normal times and during the pre-2007 crisis episodes, but they decline to $5.1 \%$ during the recent financial crisis.

To classify firms as financially weak or healthy, we apply Hadlock and Pierce's (2010) criteria. Their index considers firm size and age as predictors of the extent firms face financial constraints. The size-age-index (SA-index) is calculated as follows:

SA-index $=-0.737 \times$ Size $+0.043 \times$ Size $^{2}-0.040 \times$ Age,

where Size is the natural logarithm of total assets, and Age denotes the number of years a firm has non-missing stock price data in Compustat North America. A higher (lower) SA-index value is consistent with greater (smaller) financing obstacles. Firm-year observations with a high SA-index value (above the $60 \%$ percentile) are classified as financially weak; firm-year observations with a low SA-index value (below the $40 \%$ percentile) are considered financially healthy. ${ }^{13}$

Panels B and C of Table 1 report descriptive statistics for the subsamples of financially weak and healthy firms, respectively. The negative average cash flows $(-0.5 \%)$ and the high standard deviation (1.2\%) for the full sample in Panel A come from weak firms (Panel B), which have mean cash flows that are negative $(-10.6 \%)$ with a high standard deviation (1.8\%). In contrast, healthy firms (Panel C) exhibit mean cash flows of 7.1\%, with a low standard deviation $(0.1 \%)$. While cash flows decline for weak firms when moving from normal times $(-9.4 \%)$ to the pre-2007 crises $(-10.5 \%)$ and to the recent financial crisis $(-24.4 \%)$, the cash flows of healthy firms remain fairly stable through these economic states (between $7.0 \%$ and $8.6 \%$ ). Weak firms also exhibit higher market-to-book ratios. Moreover, compared to healthy firms, they distribute fewer funds to shareholders and issue more equity. They also borrow more and

\footnotetext{
13 As a robustness check, we also use Altman's (1968) Z-score to assess the differences in the behavior between financially weak and healthy firms.
} 
Table 1

Descriptive statistics.

Panel A: full samples

\begin{tabular}{|c|c|c|c|c|c|c|c|c|c|c|c|c|}
\hline & \multicolumn{3}{|c|}{$\begin{array}{l}\text { Full sample } \\
1972-2011\end{array}$} & \multicolumn{3}{|c|}{$\begin{array}{l}\text { Normal times } \\
1972-2011\end{array}$} & \multicolumn{3}{|c|}{$\begin{array}{l}\text { Pre-2007 crises } \\
1972-2006\end{array}$} & \multicolumn{3}{|c|}{$\begin{array}{l}\text { Recent financial crisis } \\
\text { 2007-2009 }\end{array}$} \\
\hline & $\mathrm{N}$ & Mean & SD & $\mathrm{N}$ & Mean & SD & $\mathrm{N}$ & Mean & SD & $\mathrm{N}$ & Mean & SD \\
\hline Cash flow & 217,900 & -0.005 & 1.163 & 143,501 & -0.001 & 0.627 & 62,086 & -0.006 & 1.923 & 12,313 & -0.054 & 0.828 \\
\hline Capital expenditures & 217,900 & 0.065 & 0.086 & 143,501 & 0.066 & 0.086 & 62,086 & 0.066 & 0.088 & 12,313 & 0.051 & 0.078 \\
\hline Acquisitions & 217,900 & 0.016 & 0.062 & 143,501 & 0.016 & 0.062 & 62,086 & 0.014 & 0.062 & 12,313 & 0.023 & 0.073 \\
\hline Asset sales & 217,900 & 0.010 & 0.092 & 143,501 & 0.009 & 0.082 & 62,086 & 0.013 & 0.118 & 12,313 & 0.005 & 0.053 \\
\hline Share repurchases & 217,900 & 0.010 & 0.055 & 143,501 & 0.009 & 0.057 & 62,086 & 0.009 & 0.051 & 12,313 & 0.018 & 0.059 \\
\hline Dividends & 217,900 & 0.011 & 0.097 & 143,501 & 0.011 & 0.103 & 62,086 & 0.011 & 0.087 & 12,313 & 0.011 & 0.077 \\
\hline Equity issues & 217,900 & 0.061 & 0.234 & 143,501 & 0.065 & 0.230 & 62,086 & 0.052 & 0.248 & 12,313 & 0.059 & 0.194 \\
\hline$\Delta$ Long-term debt & 217,900 & 0.008 & 0.921 & 143,501 & 0.013 & 0.316 & 62,086 & -0.003 & 1.653 & 12,313 & -0.003 & 0.253 \\
\hline$\Delta$ Short-term debt & 217,900 & 0.000 & 0.473 & 143,501 & 0.002 & 0.353 & 62,086 & -0.004 & 0.674 & 12,313 & -0.004 & 0.454 \\
\hline$\Delta$ Cash balances & 217,900 & 0.004 & 0.511 & 143,501 & 0.008 & 0.529 & 62,086 & -0.002 & 0.417 & 12,313 & -0.022 & 0.689 \\
\hline Market-to-book & 217,900 & 1.442 & 0.886 & 143,501 & 1.445 & 0.897 & 62,086 & 1.399 & 0.848 & 12,313 & 1.619 & 0.917 \\
\hline Firm size & 217,900 & 4.447 & 2.338 & 143,501 & 4.465 & 2.288 & 62,086 & 4.199 & 2.400 & 12,313 & 5.486 & 2.306 \\
\hline
\end{tabular}

Panel B: financially weak firms

\begin{tabular}{|c|c|c|c|c|c|c|c|c|c|c|c|c|}
\hline & \multicolumn{3}{|c|}{$\begin{array}{l}\text { Full sample } \\
1972-2011\end{array}$} & \multicolumn{3}{|c|}{$\begin{array}{l}\text { Normal times } \\
1972-2011\end{array}$} & \multicolumn{3}{|c|}{$\begin{array}{l}\text { Pre-2007 crises } \\
1972-2006\end{array}$} & \multicolumn{3}{|c|}{$\begin{array}{l}\text { Recent financial crisis } \\
\text { 2007-2009 }\end{array}$} \\
\hline & $\mathrm{N}$ & Mean & SD & $\mathrm{N}$ & Mean & SD & $\mathrm{N}$ & Mean & SD & $\mathrm{N}$ & Mean & SD \\
\hline Cash flow & 87,155 & -0.106 & 1.825 & 57,397 & -0.094 & 0.967 & 24,834 & -0.105 & 3.033 & 4924 & -0.244 & 1.276 \\
\hline Capital expenditures & 87,155 & 0.067 & 0.104 & 57,397 & 0.068 & 0.103 & 24,834 & 0.069 & 0.107 & 4924 & 0.048 & 0.088 \\
\hline Acquisitions & 87,155 & 0.012 & 0.058 & 57,397 & 0.012 & 0.059 & 24,834 & 0.010 & 0.055 & 4924 & 0.016 & 0.069 \\
\hline Asset sales & 87,155 & 0.015 & 0.141 & 57,397 & 0.013 & 0.125 & 24,834 & 0.020 & 0.180 & 4924 & 0.006 & 0.077 \\
\hline Share repurchases & 87,155 & 0.008 & 0.066 & 57,397 & 0.008 & 0.069 & 24,834 & 0.008 & 0.062 & 4924 & 0.009 & 0.052 \\
\hline Dividends & 87,155 & 0.009 & 0.148 & 57,397 & 0.009 & 0.159 & 24,834 & 0.008 & 0.128 & 4924 & 0.009 & 0.107 \\
\hline Equity issues & 87,155 & 0.115 & 0.348 & 57,397 & 0.122 & 0.339 & 24,834 & 0.098 & 0.377 & 4924 & 0.118 & 0.287 \\
\hline$\Delta$ Long-term debt & 87,155 & -0.006 & 1.444 & 57,397 & 0.004 & 0.468 & 24,834 & -0.028 & 2.605 & 4924 & -0.001 & 0.352 \\
\hline$\Delta$ Short-term debt & 87,155 & -0.005 & 0.733 & 57,397 & -0.002 & 0.542 & 24,834 & -0.012 & 1.053 & 4924 & -0.014 & 0.707 \\
\hline$\Delta$ Cash balances & 87,155 & -0.006 & 0.795 & 57,397 & 0.004 & 0.823 & 24,834 & -0.017 & 0.648 & 4924 & -0.066 & 1.080 \\
\hline Market-to-book & 87,155 & 1.560 & 1.066 & 57,397 & 1.549 & 1.069 & 24,834 & 1.541 & 1.047 & 4924 & 1.789 & 1.097 \\
\hline Firm size & 87,155 & 2.397 & 1.453 & 57,397 & 2.463 & 1.418 & 24,834 & 2.039 & 1.400 & 4924 & 3.436 & 1.502 \\
\hline
\end{tabular}

Panel C: financially healthy firms

\begin{tabular}{|c|c|c|c|c|c|c|c|c|c|c|c|c|}
\hline & \multicolumn{3}{|c|}{$\begin{array}{l}\text { Full sample } \\
1972-2011\end{array}$} & \multicolumn{3}{|c|}{$\begin{array}{l}\text { Normal times } \\
1972-2011\end{array}$} & \multicolumn{3}{|c|}{$\begin{array}{l}\text { Pre-2007 crises } \\
1972-2006\end{array}$} & \multicolumn{3}{|c|}{$\begin{array}{l}\text { Recent financial crisis } \\
\text { 2007-2009 }\end{array}$} \\
\hline & $\mathrm{N}$ & Mean & SD & $\mathrm{N}$ & Mean & SD & $\mathrm{N}$ & Mean & SD & $\mathrm{N}$ & Mean & SD \\
\hline Cash flow & 87,159 & 0.071 & 0.121 & 57,402 & 0.070 & 0.118 & 24,833 & 0.070 & 0.129 & 4924 & 0.086 & 0.118 \\
\hline Capital expenditures & 87,159 & 0.064 & 0.067 & 57,402 & 0.066 & 0.068 & 24,833 & 0.063 & 0.063 & 4924 & 0.053 & 0.065 \\
\hline Acquisitions & 87,159 & 0.019 & 0.062 & 57,402 & 0.019 & 0.059 & 24,833 & 0.017 & 0.065 & 4924 & 0.027 & 0.072 \\
\hline Asset sales & 87,159 & 0.006 & 0.029 & 57,402 & 0.005 & 0.024 & 24,833 & 0.007 & 0.039 & 4924 & 0.004 & 0.027 \\
\hline Share repurchases & 87,159 & 0.012 & 0.046 & 57,402 & 0.011 & 0.047 & 24,833 & 0.010 & 0.041 & 4924 & 0.026 & 0.060 \\
\hline Dividends & 87,159 & 0.014 & 0.034 & 57,402 & 0.014 & 0.029 & 24,833 & 0.016 & 0.042 & 4924 & 0.013 & 0.035 \\
\hline Equity issues & 87,159 & 0.017 & 0.056 & 57,402 & 0.018 & 0.059 & 24,833 & 0.015 & 0.053 & 4924 & 0.015 & 0.045 \\
\hline$\Delta$ Long-term debt & 87,159 & 0.016 & 0.127 & 57,402 & 0.018 & 0.122 & 24,833 & 0.013 & 0.137 & 4924 & 0.004 & 0.130 \\
\hline$\Delta$ Short-term debt & 87,159 & 0.003 & 0.093 & 57,402 & 0.004 & 0.083 & 24,833 & 0.001 & 0.112 & 4924 & 0.000 & 0.095 \\
\hline$\Delta$ Cash balances & 87,159 & 0.008 & 0.077 & 57,402 & 0.008 & 0.076 & 24,833 & 0.007 & 0.077 & 4924 & 0.008 & 0.089 \\
\hline Market-to-book & 87,159 & 1.354 & 0.698 & 57,402 & 1.367 & 0.719 & 24,833 & 1.292 & 0.634 & 4924 & 1.511 & 0.726 \\
\hline Firm size & 87,159 & 6.407 & 1.641 & 57,402 & 6.378 & 1.623 & 24,833 & 6.299 & 1.637 & 4924 & 7.298 & 1.606 \\
\hline
\end{tabular}

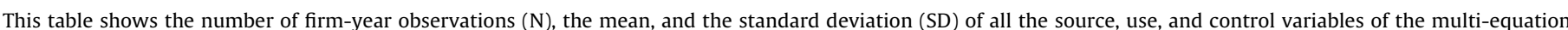

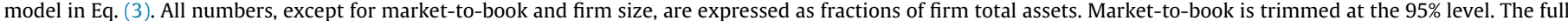

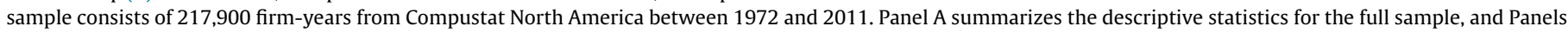

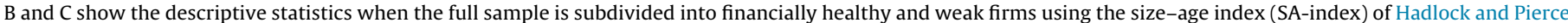

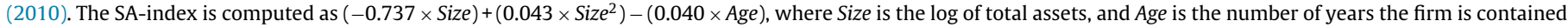

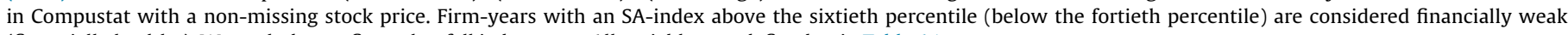
(financially healthy). We exclude any firms that fall in between. All variables are defined as in Table A1.

rely less on internal financing in all subperiods. This behavior of weak firms supports the findings in the literature (Fama \& French, 2005; Gatchev, Spindt, \& Tarhan, 2009).

\subsection{Estimating the investment-cash flow sensitivity: single- versus multi-equation models}

Before we present our main findings, we document the superiority of our multi-equation model by comparing estimates of the investment-cash flow sensitivities based on the single- and the multi-equation methodology. Panel A of Fig. 1 compares the estimates of investment-cash flow sensitivities for the pooled sample of financially weak and healthy firms over non-crisis and liquidity crisis periods using both the single and multi-equation approach. As in Chen and Chen (2012), we find that the single-equation estimates of investment-cash flow sensitivities were unaffected during the recent financial crisis; in fact, they actually declined. In contrast, the estimates obtained from our multi-equation model show that investment-cash flow sensitivities increased during this period. 
Panel A: All Firms

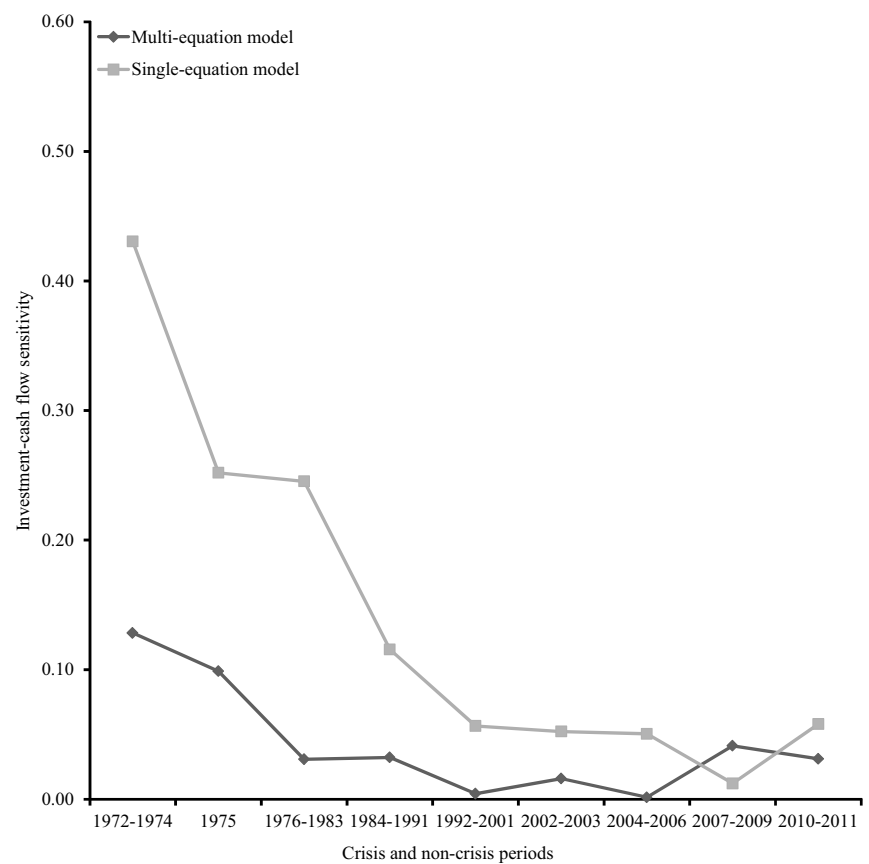

Panel B: Financially Weak versus Healthy Firms

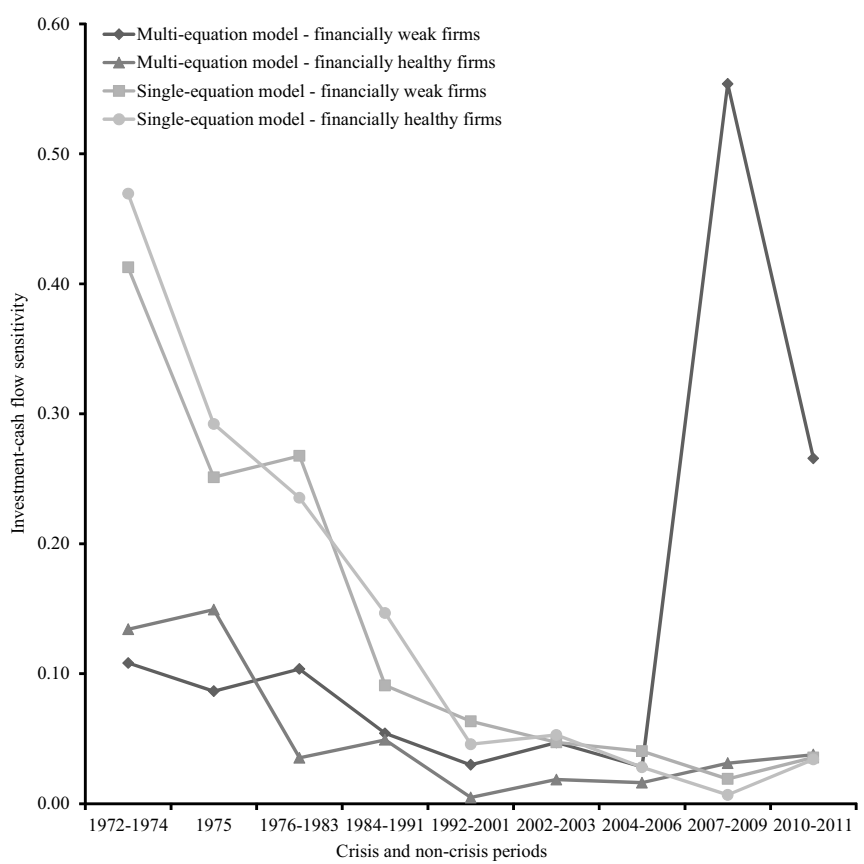

Fig. 1. Comparison of single- and multi-equation estimates.

This figure plots the investment-cash flow sensitivity coefficients using two different models. First, the single-equation model is defined as in Fazzari et al. (1988) and Chen and Chen (2012): $\frac{C_{A P X_{i, t}}}{P P E N T_{i, t-1}}=a_{t}+a_{i}+b_{1} \times Q_{i, t-1}+b_{2} \times \frac{C F L_{i, t}}{P P E N T_{i, t-1}}+\varepsilon_{i, t}$, where $\frac{C^{2} X_{i, t}}{P P E N T_{i, t-1}}$ is the firm's capital expenditures, deflated by its beginning-of-period net property, plant, and equipment, $Q_{i, t-1}$ is the previous year's Tobin's $q$, and $\frac{C F L_{i, t}}{P P E N T_{i, t-1}}$ is the firm's internal cash flow (depreciation and amortization plus income before extraordinary items), deflated by its beginning-of-period net property, plant, and equipment. $b_{2}$ is the single-equation investment-cash flow sensitivity coefficient. The model includes within firm and year fixed effects. Second, the multi-equation model is specified as in Eq. (3), and estimated subject to the constraints in Eq. (4). All the variables of this model are defined as in Table A1. Both models are estimated over time, using nine subsamples that reflect the crisis and non-crisis periods in our sample, which are described in Section 2.3. In Panel A, the model is estimated using all firms in the sample; in Panel B, we differentiate between financially weak and healthy firms by using the size-age-index (SA-index) of Hadlock and Pierce (2010). The index is computed as $(-0.737 \times$ Size $)+\left(0.043 \times\right.$ Size $\left.{ }^{2}\right)-(0.040 \times A g e)$, where Size is the log of total assets, and Age is the number of years the firm is contained in Compustat North America with a non-missing stock price. Firm-years with an SA-index above the sixtieth percentile (below the fortieth percentile) are considered financially weak (financially healthy).

Therefore, the single-equation estimates fail to verify the findings of the recent literature on the subprime mortgage crisis.

When we examine financially healthy and weak firms separately in Panel B of Fig. 1, the estimates from the single-equation model suggest that, even for financially weak firms, the investment-cash flow sensitivity was not affected during the recent financial crisis. In contrast, the investment-cash flow sensitivities from the multiequation model confirm that the impact of the recent financial crisis on capital expenditures was particularly severe for financially weak firms. Most important, the multi-equation estimate for the capital expenditure-cash flow sensitivity coefficient soars to 0.554 , implying that financially weak firms had to cut capital expenditures by $\$ 0.554$ in response to a $\$ 1$ shortfall in cash flows during the recent financial crisis. ${ }^{14}$ The evidence of the single-equation estimates that even financially weak firms were able to raise capital during

\footnotetext{
14 The $\$ 0.55$ cut in capital expenditures of financially weak firms during this period is about eighteen times larger than the estimate for the same firms during the three previous liquidity crises that we consider here $(\$ 0.03$ versus $\$ 0.55$; the difference is significant at the $1 \%$ level). When we estimate a modified version of the singleequation model that includes lagged capital expenditures as an explanatory variable, we observe that investment-cash flow sensitivities decline. However, they remain much higher than the estimates from the multi-equation model, where each equation includes not only its own lagged dependent variable, but all lagged dependent variables in the system. The presence of a positive omitted variables bias may explain the puzzle reported in earlier studies that estimates of investment-cash flow sensitivities are large and significant even for subsamples of financially healthy firms. Previous studies provide no explanation for this contradictory result. We posit that it is an artifact of the omitted variables bias, which inflates the size of investment-cash flow sensitivities for both types of firms.
}

such a severe liquidity crisis is surprising, and it raises concerns about the ability of a single-equation model to adequately capture capital market access constraints.

\section{Behavior of firms during crisis and non-crisis periods}

The question of how investment-cash flow sensitivities vary with liquidity conditions of the economy has received little attention in the literature. Anecdotal evidence suggests that, during severe liquidity crises, firms face more difficulties in raising funds to finance their investments and operations. In Section 3.1, we examine whether including the recent financial crisis, which is considered to be the most severe liquidity crisis since the Great Depression (Brunnermeier, 2009), affects cash flow sensitivities estimates. Section 3.2 proceeds by estimating our multi-equation model for different subsamples of crisis and non-crisis periods to analyze how capital market access constraints increase with the severity of a crisis. Section 3.3 analyzes the symmetry of firms' reactions to cash flow changes. Since the pooled sample of firms could mask important differences between financially weak and healthy firms, in Section 3.4 we estimate our model separately for financially weak and healthy firms.

\subsection{The effect of the recent financial crisis on cash flow sensitivities}

In this section, we assess whether the recent financial crisis was indeed severe by comparing the cash flow sensitivity estimates 
that result from our multi-equation model for sample periods that exclude and include the 2007-2009 crisis. We first estimate the system of equations model in Eq. (3), subject to the conditions in Eq. (4), for the full sample period and for the full sample period excluding the 2007-2009 crisis. We then compare the two sets of estimates to assess whether the inclusion of such a severe crisis produces estimates that suggest firms face frictions in raising funds. We implement our tests separately for both the pooled sample of firms and for financially weak and healthy firms.

Panel A of Table 2 displays the estimates of the cash flow sensitivities for the nine variables in our multi-equation model (the elements of vector $\boldsymbol{L}$ ). All variables are measured in levels, and to account for year fixed effects, we subtract annual means from each variable. ${ }^{15}$ For all subsample estimations, we base the weights and annual means on the respective subsamples. Columns (1) and (4) show the results for the pooled sample of financially weak and healthy firms. The results for the financially weak firm subsample are presented in columns (2) and (5), while columns (3) and (6) display the results for the financially healthy firm subsample. Panel B shows the stratified bootstrap tests for differences between the estimates. $^{16}$

If including the recent financial crisis generates cash flow sensitivities that indicate firms face higher hurdles in raising funds, then the estimates of the traditional capital access constraint measure could also be affected. A first result that is reassuring for our model is that 48 of the 54 estimated coefficients in Table 2 have the expected signs. For example, column (1) shows that when firms experience a $\$ 1$ decline in cash flows (a source variable), they reduce investments (both capital expenditures and acquisitions decline), increase asset sales, issue equity, reduce shareholder payouts in the form of both dividends and share repurchases, increase their short- and long-term borrowings, and draw down their cash holdings.

Column (1) of Panel A shows our results from the full sample period excluding the 2007-2009 financial crisis for the pooled sample of financially weak and healthy firms, while column (4) contains the results for the pooled sample of firms when the recent financial crisis is included. Stratified bootstrap difference tests of column (1) minus column (4) are shown in column (1) of Panel B. With the exception of cash balances (significant at the $10 \%$ level), all paired differences in the estimates lack statistical significance. Inclusion or exclusion of the recent financial crisis does not affect the estimates for the pooled sample of financially weak and healthy firms. However, these results may mask differences between financially weak and healthy firms, and we next estimate the model for these two types of firms separately.

The estimates for financially healthy firms are in columns (3) and (6) of Panel A. The patterns displayed by healthy firms for the full sample period with and without the recent financial crisis are similar to the behavior of the pooled sample of weak and healthy firms. In fact, the stratified bootstrap difference tests in column (5) of Panel B show that again only cash balances exhibit marginal statistical significance. In contrast, the estimates for financially weak firms in columns (2) and (5) of Panel A are sensitive to the inclusion/exclusion of the recent financial crisis in the full sample period. ${ }^{17}$ Weak firms are adversely affected by the recent

\footnotetext{
15 As a robustness test, we repeat the analysis measuring variables in first differences using Cleary's (1999) methodology. Our results (not reported) are robust with respect to how variables are measured.

16 We bootstrap the $p$-values of the difference test using stratified sampling with 1000 iterations. For the full sample, we divide firms into three groups of equal size (financially weak, neutral, and financially healthy), using Hadlock and Pierce's (2010) size-age index as a measure of financial constraints.

17 When we exclude the recent financial crisis from the sample period, column (2) shows that six of the nine estimated cash flow sensitivities of financially weak firms
}

financial crisis, and including the 2007-2009 crisis in the sample results in a bigger cut in capital expenditures and in lower longterm borrowings when firms face cash flow shortfalls (column (4) of Panel B).

The traditional metric of constrained access to external capital markets tests whether the differences between the estimates for financially weak and healthy firms are significantly different, as reported in columns (2) and (3) of Panel B. When the recent financial crisis is excluded from the full sample period (column (2)), we observe that only the differences in share repurchases and in changes in cash holdings show marginal statistical significance. However, when this crisis is included in the full sample period (column (3)), we find that weak firms cut their capital expenditures significantly more than healthy firms, they borrow less short- and long-term funds, issue more equity, and rely less on cash balances (less internal borrowing).

To summarize, neither the estimates for financially healthy firms nor the pooled sample of financially healthy and weak firms are affected by the inclusion/exclusion of the recent financial crisis in the sample period. However, financially weak firms are affected adversely when this crisis is included in the sample period. When the data includes the recent financial crisis, the traditionally defined capital market frictions become tighter, suggesting that the occurrence of liquidity crises is positively correlated with the traditional measure of capital market frictions.

\subsection{Capital market access constraints and crisis severity: the pooled sample of firms}

We next examine whether the link between capital market access constraints of the pooled sample of financially weak and healthy firms increases with liquidity crisis severity. In particular, we estimate our model for the pooled sample of financially weak and healthy firms, and compare the coefficient estimates for the full sample period and the three subsample periods: (1) non-crisis years, (2) the three moderate pre-2007 liquidity crises, and (3) the 2007-2009 crisis. Again, only the estimates for the elements of vector $\boldsymbol{L}$ are reported in Table $3 .{ }^{18}$ The table includes two additional rows for total borrowings: $\Delta$ Total debt, defined as the sum of the estimates for short- and long-term debt issues, and $\Delta$ Leverage, defined as total debt issues plus changes in cash holdings.

There are six main findings in Table 3. First, Panel A shows that the directions of the responses are robust to the choice of sample period. In fact, except for equity issues (which are economically small), the estimates for the cash flow sensitivities have the same signs in all four sample periods. Second, 33 of the 36 estimated coefficients have the expected sign. In response to a cash flow shortfall,

have the expected signs. Only one of the five statistically significant coefficients has an "incorrect" sign. The coefficient for financially weak firms' asset sales is positive and statistically significant at the $5 \%$ level, indicating that weak firms respond to cash flow shortfalls by reducing asset sales (although the $\$ 0.01$ change is economically small). When we include the subprime mortgage crisis, even eight of the nine coefficients for the weak firm subsample in column (5) have the "correct" sign, and seven of these are statistically significant.

18 Both Tables 2 and 3 do not report the estimates for the own-lagged dependent variables (estimates for the diagonal elements of matrix $\boldsymbol{K}$ ) and the two exogenous variables $M B$ and SIZE (estimates for the elements of matrix $\boldsymbol{M}$ ). Because these variables represent neither sources nor uses of funds in the current period, the estimates should sum to zero across the system of equations. The estimates for lagged dependent variables (not reported) are consistent with the notion that adjusting real assets entails high costs, while the adjustment costs of financing variables is relatively low. There is more persistence in real assets, and ignoring their lags in the specifications of cash flow sensitivity regressions can cause significant omitted variable biases. More detailed results are available upon request. 
Table 2

Full sample estimates.

Panel A: cash flow sensitivities

\begin{tabular}{|c|c|c|c|c|c|c|}
\hline & \multicolumn{3}{|c|}{ Full sample 1972-2011 (excluding 2007-2009) } & \multicolumn{3}{|c|}{ Full sample 1972-2011 } \\
\hline & All firms (1) & Weak firms (2) & Healthy firms (3) & All firms (4) & Weak firms (5) & Healthy firms (6) \\
\hline Capital expenditures $s_{t}$ & 0.017 & 0.021 & 0.020 & 0.031 & $0.316^{* *}$ & 0.030 \\
\hline Acquisitions $_{\mathrm{t}}$ & 0.021 & $0.017^{* * *}$ & 0.017 & 0.033 & $0.021^{* *}$ & 0.028 \\
\hline Asset sales $_{\mathrm{t}}$ & -0.006 & $0.010^{* *}$ & -0.007 & -0.005 & $0.023^{*}$ & -0.005 \\
\hline Share repurchases ${ }_{t}$ & $0.041^{*}$ & -0.006 & 0.038 & $0.044^{*}$ & 0.004 & 0.042 \\
\hline Dividends $\mathrm{s}_{\mathrm{t}}$ & 0.028 & $0.026^{* * *}$ & 0.028 & $0.030^{*}$ & $0.022^{* *}$ & 0.028 \\
\hline Equity issues $_{t}$ & -0.001 & -0.040 & -0.001 & 0.002 & $-0.087^{* *}$ & 0.002 \\
\hline$\Delta$ Long-term debt $t_{t}$ & $-0.417^{* * *}$ & $-0.461^{* * *}$ & $-0.416^{* * *}$ & $-0.307^{* * *}$ & $-0.118^{* *}$ & $-0.310^{* * *}$ \\
\hline$\Delta$ Short-term debt $_{\mathrm{t}}$ & $-0.400^{* * *}$ & $-0.476^{* * *}$ & $-0.408^{* * *}$ & $-0.395^{* * *}$ & $-0.346^{* * *}$ & $-0.404^{* * *}$ \\
\hline$\Delta$ Cash balances $_{t}$ & 0.068 & -0.025 & 0.065 & $0.157^{* * *}$ & $0.109^{* * *}$ & $0.154^{* * *}$ \\
\hline$\Delta$ Uses $_{\mathrm{t}}+\Delta$ Sources $_{\mathrm{t}}$ & 1.000 & 1.000 & 1.000 & 1.000 & 1.000 & 1.000 \\
\hline Number of observations & 205,587 & 82,230 & 82,235 & 217,900 & 87,155 & 87,159 \\
\hline
\end{tabular}

Panel B: bootstrap difference tests

\begin{tabular}{|c|c|c|c|c|c|}
\hline & $\begin{array}{l}\text { Difference in cash flow } \\
(1):(1)-(4)\end{array}$ & $\begin{array}{l}\text { Difference in cash flow }{ }_{t} \\
(2):(2)-(3)\end{array}$ & $\begin{array}{l}\text { Difference in cash flow } \\
(3):(5)-(6)\end{array}$ & $\begin{array}{l}\text { Difference in cash flow } \\
(4):(2)-(5)\end{array}$ & $\begin{array}{l}\text { Difference in cash flow } \\
(5):(3)-(6)\end{array}$ \\
\hline Capital expenditures $s_{t}$ & -0.014 & 0.001 & $0.285^{* *}$ & $-0.295^{* *}$ & -0.010 \\
\hline Acquisitions $_{\mathrm{t}}$ & -0.012 & 0.000 & -0.007 & -0.004 & -0.011 \\
\hline Asset sales $t_{t}$ & -0.002 & 0.017 & $0.029^{*}$ & -0.013 & -0.001 \\
\hline Share repurchases $_{\mathrm{t}}$ & -0.003 & $-0.044^{*}$ & $-0.038^{* *}$ & -0.010 & -0.004 \\
\hline Dividends $_{t}$ & -0.002 & -0.002 & -0.006 & 0.004 & 0.000 \\
\hline Equity issues $_{t}$ & -0.003 & -0.039 & $-0.089^{* *}$ & 0.047 & -0.003 \\
\hline$\Delta$ Long-term debt $t_{t}$ & -0.111 & -0.045 & $0.192^{* *}$ & $-0.343^{* *}$ & -0.106 \\
\hline$\Delta$ Short-term debt $t_{t}$ & -0.005 & -0.067 & $0.058^{*}$ & -0.129 & -0.004 \\
\hline$\Delta$ Cash balances $_{\mathrm{t}}$ & $-0.090^{*}$ & $-0.089^{*}$ & $-0.046^{*}$ & -0.134 & $-0.090^{*}$ \\
\hline
\end{tabular}

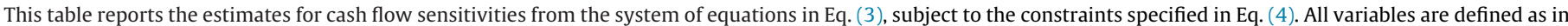

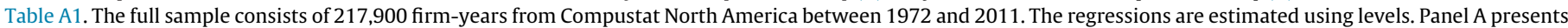

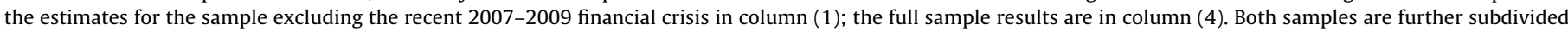

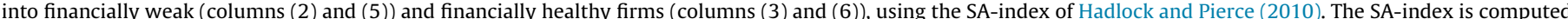

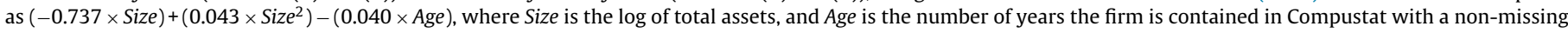

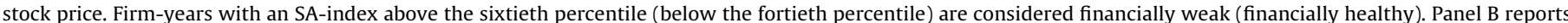

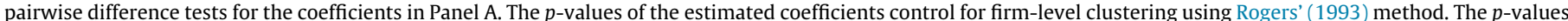
of the difference test are bootstrapped using stratified sampling and 1000 iterations. ${ }^{* * *}$, ${ }^{* *}$, and ${ }^{*}$ denote significance at the $1 \%, 5 \%$, and $10 \%$ levels, respectively.

investment and payout variables decline, while asset sales, borrowings, and use of cash balances increase. ${ }^{19}$

Third, Panel A shows that the estimates for the cash flow sensitivity of capital expenditures increase monotonically as liquidity conditions in the economy become tighter. However, the estimates are economically small - ranging from 0.007 to 0.041 - and their statistical significance during the moderate and severe liquidity crisis periods is only marginal (columns (3) and (4)). We find no statistical significance for any of the stratified bootstrap difference tests in Panel B that compare the cash flow sensitivity of capital expenditures in the three liquidity regimes.

We note that a recurring finding in our analyses is that the biggest reactions to cash flow shocks, and most of the statistically significant coefficients, are observed in the leverage equations. In fact, cash flow sensitivities of short-term borrowings, longterm debt issues, and changes in cash balances dominate both investment and distribution responses. ${ }^{20}$ In other words, while single-equation models focus on capital expenditures to detect capital market frictions, our results indicate that capital market frictions are reflected primarily in borrowing variables and cash balances rather than in capital expenditures.

\footnotetext{
19 Only the cash flow sensitivity estimates for equity issues in the full sample period and the two liquidity crisis subsample periods have "incorrect" signs; however, none of the three equity issue coefficients with the "incorrect" sign is statistically significant. For the other variables in the model, 20 of the coefficients are statistically significant.

${ }^{20}$ Because the coefficient estimates for equity issues are both economically small and statistically insignificant for all three subperiods, we do not comment on them here. Cash flow sensitivities of shareholder distributions (dividends and share repurchases) are also relatively small.
}

Fourth, the more severe the liquidity crisis, the tighter are the restrictions firms face in debt markets. When firms experience a $\$ 1$ shortfall in cash flows during non-crisis years, they increase their total borrowings by $\$ 0.843$ and their leverage by $\$ 0.905$. When the shortfall in cash flows occurs during the three pre-2007 crises, we observe that firms use slightly less debt (\$0.776) and leverage (\$0.873), suggesting that even moderate liquidity crises have some adverse effects on firms' financing activities. Total debt declines even more dramatically during the recent financial crisis (\$0.475). One could argue that using \$0.067 less borrowings and having $\$ 0.032$ worth of lower leverage during the moderate crisis episodes relative to non-crisis years is not economically meaningful. However, at times the presence of capital market frictions may be observed in the composition of the financing response, rather than in its size.

Fifth, during moderate liquidity crises, firms substitute shortterm borrowings for long-term debt; however, we find no evidence for such a substitution effect during the recent financial crisis. When a negative $\$ 1$ cash flow shock occurs during non-crisis years, firms borrow $\$ 0.478$ of long-term funds ( $57 \%$ of total debt). In contrast, during the pre-2007 liquidity crises, long-term debt issues drop to $\$ 0.187$ ( $24 \%$ of total debt), suggesting that firms face difficulties in issuing long-term debt (or long-term debt may be too costly) even during moderate liquidity crises.

The decline in long-term borrowings is consistent with the view that the effects of financing constraints are more likely to be detected in firms' long-term debt issues than in their shortterm borrowings (Gatchev et al., 2009). The stratified bootstrap difference tests in columns (1) of Panel B indicate that, relative to non-crisis years, the $\$ 0.292$ decline in long-term debt is sta- 
Table 3

Investment and financing cash flow sensitivities: crisis versus non-crisis periods.

\begin{tabular}{|c|c|c|c|c|}
\hline & $\begin{array}{l}\text { Full sample 1972-2011 } \\
\text { (1) }\end{array}$ & $\begin{array}{l}\text { Normal times } 1972-2011 \\
(2)\end{array}$ & $\begin{array}{l}\text { Pre-2007 crises } 1972-2006 \\
\text { (3) }\end{array}$ & $\begin{array}{l}\text { Recent financial crisis 2007-2009 } \\
\text { (4) }\end{array}$ \\
\hline Capital expenditures ${ }_{t}$ & 0.031 & 0.007 & $0.029^{*}$ & $0.041^{*}$ \\
\hline Acquisitions $_{t}$ & 0.033 & 0.010 & 0.046 & 0.039 \\
\hline Asset sales $t_{t}$ & -0.005 & $-0.006^{*}$ & -0.001 & -0.009 \\
\hline Share repurchases ${ }_{t}$ & $0.044^{*}$ & $0.042^{* *}$ & $0.034^{* *}$ & 0.070 \\
\hline Dividend $_{t}$ & $0.030^{*}$ & $0.028^{*}$ & $0.022^{* *}$ & $0.024^{* *}$ \\
\hline Equity issues $_{t}$ & 0.002 & -0.001 & 0.004 & 0.005 \\
\hline$\Delta$ Long-term debt $_{\mathrm{t}}$ & $-0.307^{* * *}$ & $-0.478^{* * *}$ & $-0.187^{* * *}$ & -0.093 \\
\hline$\Delta$ Short-term debt $_{\mathrm{t}}$ & $-0.395^{* * *}$ & $-0.365^{* * *}$ & $-0.589^{* * *}$ & $-0.382^{* * *}$ \\
\hline$\Delta$ Cash balances $_{\mathrm{t}}$ & $0.157^{* * *}$ & 0.062 & $0.097^{* * *}$ & $0.348^{* * *}$ \\
\hline$\Delta$ Uses $_{\mathrm{t}}+\Delta$ Sources $_{\mathrm{t}}$ & 1.000 & 1.000 & 1.000 & 1.000 \\
\hline$\Delta$ Total debt $_{t}$ & 0.702 & 0.843 & 0.776 & 0.475 \\
\hline$\Delta$ Leverage $_{t}$ & 0.859 & 0.905 & 0.873 & 0.822 \\
\hline Number of observations & 217,900 & 143,501 & 62,086 & 12,313 \\
\hline
\end{tabular}

Panel B: bootstrap difference tests

\begin{tabular}{|c|c|c|c|}
\hline & $\begin{array}{l}\text { Difference in cash flow } \\
(1):(2)-(3)\end{array}$ & $\begin{array}{l}\text { Difference in cash flow } \\
(2):(2)-(4)\end{array}$ & $\begin{array}{l}\text { Difference in cash flow } \\
\text { (3): (3)-(4) }\end{array}$ \\
\hline Capital expenditures ${ }_{t}$ & -0.022 & -0.034 & -0.012 \\
\hline Acquisitions $_{t}$ & -0.036 & -0.029 & 0.007 \\
\hline Asset sales & -0.006 & 0.002 & 0.008 \\
\hline Equity issues $_{t}$ & 0.008 & -0.028 & -0.036 \\
\hline Share repurchases ${ }_{t}$ & 0.007 & 0.004 & -0.003 \\
\hline Dividends $_{\mathrm{t}}$ & -0.005 & -0.006 & -0.001 \\
\hline$\Delta$ Long-term debt $_{\mathrm{t}}$ & $-0.292^{* * *}$ & $-0.386^{* * *}$ & $-0.094^{* * *}$ \\
\hline$\Delta$ Short-term debt ${ }_{t}$ & $0.224^{*}$ & 0.017 & $-0.207^{* *}$ \\
\hline$\Delta$ Cash balances $_{\mathrm{t}}$ & -0.035 & $-0.286^{* * *}$ & $-0.251^{* * *}$ \\
\hline$\Delta$ Total debt $t_{t}$ & 0.068 & $0.369^{*}$ & $0.301^{*}$ \\
\hline$\Delta$ Leverage $_{\mathrm{t}}$ & 0.033 & 0.083 & 0.050 \\
\hline
\end{tabular}

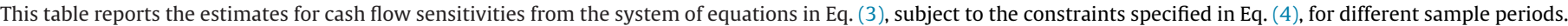

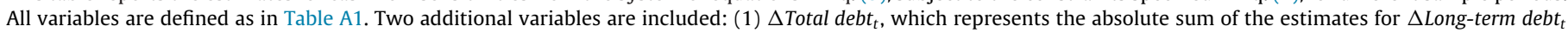

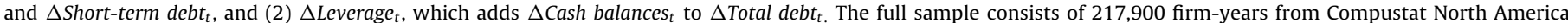

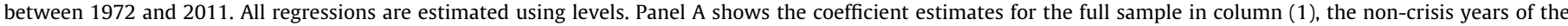

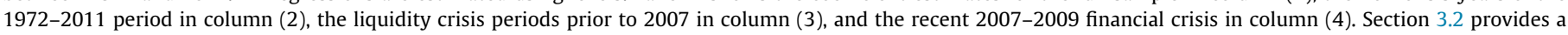

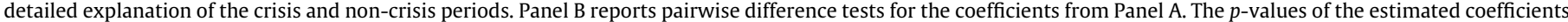

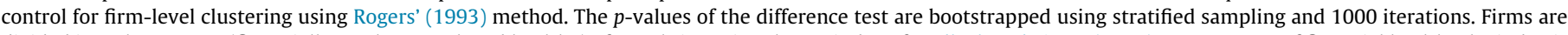

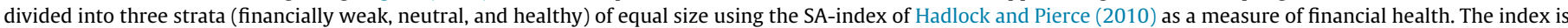

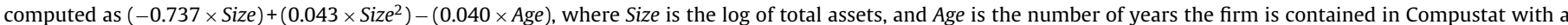

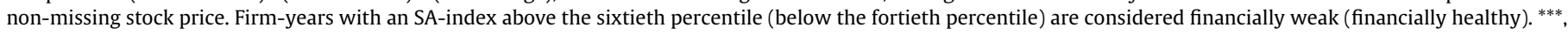
**, and * denote significance at the $1 \%, 5 \%$, and $10 \%$ levels, respectively.

tistically significant (at the 1\% level) during the pre-2007 liquidity crises. At the same time, short-term borrowings increase from their non-crisis level of $\$ 0.365$ to $\$ 0.589$; this change is significant at the $10 \%$ level. The substantial shift in the maturity composition of debt toward short-term borrowings appears to be a better indicator of the capital market frictions firms face during the moderate liquidity crises than the small decline in total debt $(\$ 0.068)$.

Long-term debt issues decline further during the recent financial crisis to $\$ 0.093$ (around $20 \%$ of total debt), which is not significantly different than zero. While firms substitute short-for long-term debt during the earlier crises relative to non-crisis periods, we do not observe this substitution effect during the recent financial crisis. In fact, short-term debt declines relative to the pre-2007 crises (from $\$ 0.589$ to $\$ 0.382$ ), implying that firms borrow essentially the same amount of short-term funds during the recent financial crisis as they do during non-crisis years ( $\$ 0.365$ versus $\$ 0.384$ ). There are several possible explanations for the differences between the cash flow sensitivities of short-term debt during the recent financial crisis and earlier liquidity crises. One possibility is that more firms violated the covenants of their lines of credit during the recent financial crisis. Banks used the escape clauses triggered by these technical defaults and renounced their lines of credit contracts with a substantial number of firms, which were likely financially weak firms. When we examine the behavior of financially weak and healthy firms (see Table 5 below), we will be able to determine whether the difference in cash flow sensitivities of short-term debt between financially weak and healthy firms increases during the 2007-2009 crisis. Another possibility is that, as notes payable matured, banks simply did not renew them, even if firms were not in technical default (Ivashina \& Scharfstein, 2010; Almeida et al., 2011)..$^{21}$

Sixth, while leverage also decreases monotonically, reductions in leverage are more muted than declines in total debt. In fact, the bootstrap difference tests show that the declines in leverage do not reach statistical significance. Because the difference between total debt and leverage is use of cash balances, the use of cash balances must offset the decline in total debt. Panel A confirms that the use of cash balances increases monotonically. While, during non-crisis years, firms draw down cash balances by $\$ 0.062$ after a $\$ 1$ decline in cash flows, this estimate increases to $\$ 0.097$ during the moderate pre-2007 crises, and to $\$ 0.348$ during the recent financial crisis (the two latter estimates are significant at the $1 \%$ level). Moreover, because cash represents negative (internal) debt, the difficulties

\footnotetext{
21 The definition of short-term debt includes the current portion of long-term debt. Firms may have been unable to offset the maturing current portion of debt with new long-term borrowings.
} 
Table 4

Testing for symmetry of positive and negative cash flow shocks.

\begin{tabular}{|c|c|c|c|}
\hline \multicolumn{4}{|l|}{ Panel A: full sample } \\
\hline & $\begin{array}{l}\text { Positive cash flow shock } \\
\text { (1) }\end{array}$ & $\begin{array}{l}\text { Negative cash flow shock } \\
\text { (2) }\end{array}$ & $\begin{array}{l}\text { Difference in cash flow } \\
(3):(1)-(2)\end{array}$ \\
\hline Capital expenditures $_{t}$ & 0.044 & 0.003 & 0.040 \\
\hline Acquisitions $_{\mathrm{t}}$ & 0.038 & 0.024 & 0.014 \\
\hline Asset sales & -0.002 & -0.010 & 0.008 \\
\hline Share repurchases ${ }_{\mathrm{t}}$ & 0.045 & $0.041^{* *}$ & 0.004 \\
\hline Dividends $_{\mathrm{t}}$ & 0.042 & 0.005 & 0.037 \\
\hline Equity issues $_{t}$ & 0.008 & $-0.009^{* *}$ & $0.016^{* *}$ \\
\hline$\Delta$ Long-term debt $t_{t}$ & $-0.268^{*}$ & $-0.400^{* * *}$ & 0.132 \\
\hline$\Delta$ Short-term debt $_{\mathrm{t}}$ & $-0.375^{* * *}$ & $-0.437^{* * *}$ & 0.062 \\
\hline$\Delta$ Cash balances $_{\mathrm{t}}$ & $0.195^{* *}$ & $0.071^{*}$ & 0.124 \\
\hline$\Delta$ Uses $_{\mathrm{t}}+\Delta$ Sources $_{\mathrm{t}}$ & 1.000 & 1.000 & \\
\hline Number of observations & 217,900 & 217,900 & \\
\hline \multicolumn{4}{|c|}{ Panel B: financially weak sample during the recent financial crisis (2007-2009) } \\
\hline & $\begin{array}{l}\text { Positive cash flow shock } \\
\text { (1) }\end{array}$ & $\begin{array}{l}\text { Negative cash flow shock } \\
(2)\end{array}$ & $\begin{array}{l}\text { Difference in cash flow } \mathrm{t} \\
(3):(1)-(2)\end{array}$ \\
\hline Capital expenditures $_{t}$ & $0.090^{* *}$ & $0.551^{* * *}$ & $-0.461^{* *}$ \\
\hline Acquisitions $_{\mathrm{t}}$ & 0.037 & 0.007 & 0.030 \\
\hline Asset sales $t_{t}$ & -0.003 & $0.041^{* * *}$ & $-0.045^{* *}$ \\
\hline Share repurchases $_{t}$ & 0.062 & 0.004 & $0.059^{*}$ \\
\hline Dividends $_{\mathrm{t}}$ & $0.052^{*}$ & 0.008 & 0.044 \\
\hline Equity issues $_{\mathrm{t}}$ & $-0.116^{*}$ & -0.036 & $-0.080^{*}$ \\
\hline$\Delta$ Long-term debt $t_{t}$ & -0.152 & -0.157 & 0.005 \\
\hline$\Delta$ Short-term debt $_{\mathrm{t}}$ & $-0.175^{* * *}$ & -0.112 & $-0.063^{*}$ \\
\hline$\Delta$ Cash balances $_{\mathrm{t}}$ & $0.313^{* * *}$ & $0.168^{* * *}$ & $0.145^{* *}$ \\
\hline$\Delta$ Uses $_{\mathrm{t}}+\Delta$ Sources $_{\mathrm{t}}$ & 1.000 & 1.000 & \\
\hline Number of observations & 4924 & 4924 & \\
\hline
\end{tabular}

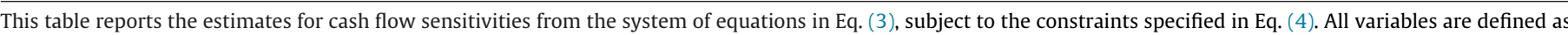

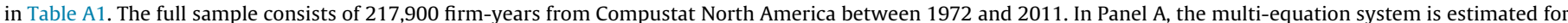

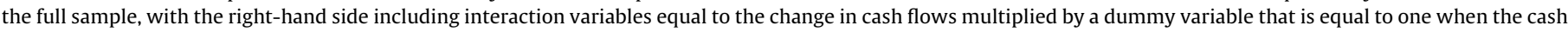

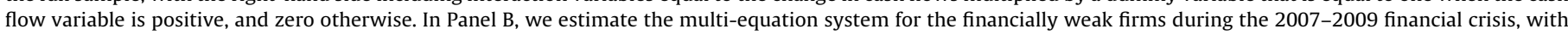

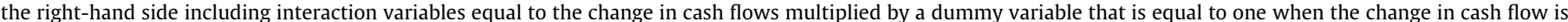

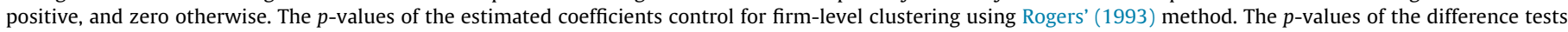

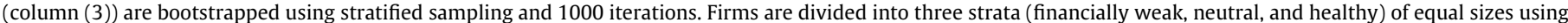

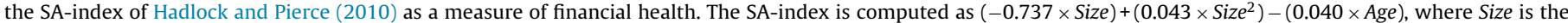

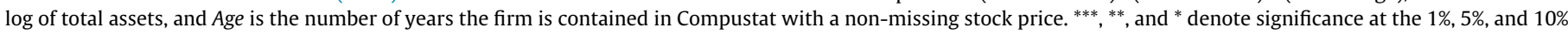
levels, respectively.

in raising external funds can thus also be detected by comparing the relative contributions of external and internal borrowings to leverage. The use of cash balances accounts for only $7 \%$ of leverage during non-crisis years, but it increases to $13 \%$ and $42 \%$ during the moderate crises and the recent financial crisis, respectively. The latter percentage provides additional evidence of the severity of the crisis.

Another observation is that our results confirm the findings in Bliss et al. (2013), who document a significant reduction in dividends and share repurchases during the financial crisis. In particular, a $\$ 1$ shortfall in cash flows induces firms to cut distributions (share repurchases plus dividends) by $\$ 0.070, \$ 0.056$, and $\$ 0.094$, during non-crisis, moderate crisis, and the subprime mortgage crisis periods, respectively. However, the stratified bootstrap difference tests reported in Panel B show that none of the differences in dividends and share repurchase estimates is statistically significant.

Overall, the results based on the pooled sample of financially weak and healthy firms indicate that firms face frictions in raising funds during liquidity crises, and that the size of the obstacles to raising funds increases with the severity of liquidity crises. We also find that firms respond to cash flow shortfalls by rearranging their financing activities, especially their borrowing decisions, rather than by changing their investments. Adjusting investment and distribution variables involves substantial costs, which likely explains firms' reluctance to use investment- and/or distribution-related instruments to counter cash flow shocks. ${ }^{22}$

\subsection{Testing the symmetry of the reactions to cash flow changes}

Our tests assume that a firm's reaction to positive cash flow changes is equal in magnitude but opposite in sign to its reaction to negative cash flow shocks. However, the presence of capital market frictions is more about being able to raise external funds when faced with negative cash flow changes than it is about retiring capital in response to positive cash flow changes. We thus interpret our

\footnotetext{
22 We implement two robustness tests for the full sample and all subsample periods. First, over the years, the U.S. economy transitioned from being dominated by industrial firms with large capital expenditures to being driven by technology firms, where the importance of capital expenditures declined and the importance of R\&D activities increased. We thus modify the investment variable by summing capita expenditures and R\&D expenses. Our results (not reported) are robust to including R\&D expenses. Second, we use quarterly instead of annual data. The benefit of this approach is that it allows for a more precise dating of the crisis periods. In particular, for the recent financial crisis, we choose the fourth quarter of 2007 as the beginning and the first quarter of 2009 as the end (Kahle \& Stulz, 2013). To capture the intertemporal nature of the Gatchev et al. (2010) model with quarterly data, we expand the system of equations in Eq. (3) and the constraints in Eq. (4) to incorporate four quarterly time lags, which leads to a system of equations model with 36 equations and thirty-nine constraints. We find that the results (not reported) produced by quarterly data are qualitatively similar to those for annual data, and thus conclude that the model is also robust with respect to frequency of the observations.
} 
Table 5

Investment and financing cash flow sensitivities: effects of financial health.

Panel A: cash flow sensitivities

\begin{tabular}{|c|c|c|c|c|c|c|}
\hline & \multicolumn{2}{|c|}{ Normal times (1972-2011) } & \multicolumn{2}{|c|}{ Pre-2007 crises (1972-2006) } & \multicolumn{2}{|c|}{ Recent financial crisis (2007-2009) } \\
\hline & $\begin{array}{l}\text { Weak firms } \\
\text { (1) }\end{array}$ & $\begin{array}{l}\text { Healthy firms } \\
\text { (2) }\end{array}$ & $\begin{array}{l}\text { Weak firms } \\
\text { (3) }\end{array}$ & $\begin{array}{l}\text { Healthy firms } \\
\text { (4) }\end{array}$ & $\begin{array}{l}\text { Weak firms } \\
\text { (5) }\end{array}$ & $\begin{array}{l}\text { Healthy firms } \\
\text { (6) }\end{array}$ \\
\hline Capital expenditures ${ }_{t}$ & 0.034 & 0.007 & $0.033^{* * *}$ & 0.030 & $0.554^{* * *}$ & $0.041^{*}$ \\
\hline Acquisitions $_{\mathrm{t}}$ & $0.013^{* *}$ & 0.005 & $0.014^{*}$ & 0.046 & 0.007 & 0.025 \\
\hline Asset sales & -0.001 & -0.007 & 0.002 & -0.001 & $0.042^{* * *}$ & $-0.010^{*}$ \\
\hline Share repurchases $_{\mathrm{t}}$ & -0.006 & 0.039* & 0.005 & $0.033^{* *}$ & 0.004 & 0.076 \\
\hline Dividend $s_{t}$ & $0.028^{* * *}$ & 0.028 & 0.015 & $0.022^{* *}$ & 0.002 & $0.018^{*}$ \\
\hline Equity issues $_{t}$ & -0.035 & -0.001 & $-0.092^{* * *}$ & 0.003 & $-0.038^{*}$ & 0.005 \\
\hline$\Delta$ Long-term debt $_{t}$ & $-0.483^{* * *}$ & $-0.479^{* * *}$ & $-0.357^{* * *}$ & $-0.185^{* * *}$ & -0.138 & -0.100 \\
\hline$\Delta$ Short-term debt $_{\mathrm{t}}$ & $-0.469^{* * *}$ & $-0.377^{* * *}$ & $-0.396^{* * *}$ & $-0.588^{* * *}$ & -0.118 & $-0.393^{* * *}$ \\
\hline$\Delta$ Cash balances $_{\mathrm{t}}$ & -0.056 & 0.057 & $0.090^{* * *}$ & $0.098^{* * *}$ & $0.181^{* * *}$ & $0.342^{* * *}$ \\
\hline$\Delta$ Uses $_{t}+\Delta$ Sources $_{t}$ & 1.000 & 1.000 & 1.000 & 1.000 & 1.000 & 1.000 \\
\hline$\Delta$ Total debt $_{\mathrm{t}}$ & 0.952 & 0.856 & 0.753 & 0.774 & 0.256 & 0.494 \\
\hline$\Delta$ Leverage $_{\mathrm{t}}$ & 0.896 & 0.913 & 0.843 & 0.872 & 0.437 & 0.836 \\
\hline Number of observations & 57,397 & 57,402 & 24,834 & 24,833 & 4924 & 4924 \\
\hline
\end{tabular}

Panel B: bootstrap difference tests

\begin{tabular}{|c|c|c|c|c|c|c|c|c|c|}
\hline & $\begin{array}{l}\text { Difference in } \\
\text { cash flow }_{t}(1) \text { : } \\
(1)-(2)\end{array}$ & $\begin{array}{l}\text { Difference in } \\
\text { cash flow }(2) \text { : } \\
(3)-(4)\end{array}$ & $\begin{array}{l}\text { Difference in } \\
\text { cash flow }{ }_{t}(3) \text { : } \\
(5)-(6)\end{array}$ & $\begin{array}{l}\text { Difference in } \\
\text { cash flow } \mathrm{w}_{\mathrm{t}}(4) \text { : } \\
(1)-(3)\end{array}$ & $\begin{array}{l}\text { Difference in } \\
\text { cash flow } \text { fl }_{t}(5) \text { : } \\
(1)-(5)\end{array}$ & $\begin{array}{l}\text { Difference in } \\
\text { cash flow }(6) \text { : } \\
(3)-(5)\end{array}$ & $\begin{array}{l}\text { Difference in } \\
\text { cash flow }_{t}(7) \text { : } \\
(2)-(4)\end{array}$ & $\begin{array}{l}\text { Difference in } \\
\text { cash flow }_{t}(8) \text { : } \\
(2)-(6)\end{array}$ & $\begin{array}{l}\text { Difference in } \\
\text { cash flow } \mathrm{t}_{\mathrm{t}}(9) \\
(4)-(6)\end{array}$ \\
\hline Capital expenditures & 0.027 & 0.002 & $0.513^{* *}$ & 0.001 & $-0.520^{* *}$ & $-0.521^{* *}$ & -0.023 & -0.034 & -0.011 \\
\hline Acquisitions $_{\mathrm{t}}$ & 0.008 & -0.031 & -0.017 & -0.001 & 0.006 & 0.007 & -0.040 & -0.019 & 0.021 \\
\hline Asset sales $_{\mathrm{t}}$ & 0.007 & 0.003 & $0.052^{*}$ & -0.003 & $-0.042^{*}$ & $-0.040^{*}$ & -0.007 & 0.003 & 0.010 \\
\hline Share repurchases ${ }_{t}$ & -0.045 & $-0.028^{*}$ & -0.072 & $-0.011^{* *}$ & -0.010 & 0.002 & 0.006 & -0.036 & -0.042 \\
\hline Dividends $s_{t}$ & 0.000 & -0.007 & -0.016 & 0.013 & $0.026^{* *}$ & 0.013 & 0.006 & 0.010 & 0.004 \\
\hline Equity issuest & -0.035 & $-0.095^{* * *}$ & -0.043 & 0.057 & 0.003 & -0.054 & -0.004 & -0.006 & -0.002 \\
\hline$\Delta$ Long-term debt $_{\mathrm{t}}$ & -0.004 & $-0.171^{* *}$ & -0.038 & $-0.126^{* *}$ & $-0.345^{* * *}$ & $-0.219^{* *}$ & $-0.294^{* *}$ & $-0.379^{* * *}$ & -0.085 \\
\hline$\Delta$ Short-term debt $t_{\mathrm{t}}$ & -0.092 & $0.192^{*}$ & $0.275^{* *}$ & $-0.073^{* * *}$ & $-0.351^{*}$ & $-0.278^{* *}$ & $0.212^{*}$ & 0.017 & $-0.195^{* *}$ \\
\hline$\Delta$ Cash balances $_{\mathrm{t}}$ & $-0.113^{*}$ & -0.008 & $-0.161^{* *}$ & $-0.146^{* * *}$ & $-0.237^{* * *}$ & $-0.091^{*}$ & -0.041 & $-0.285^{* * *}$ & $-0.244^{* * *}$ \\
\hline$\Delta$ Total debt $_{\mathrm{t}}$ & 0.096 & -0.021 & -0.238 & $0.199^{* *}$ & $0.696^{* * *}$ & $0.497^{* * *}$ & 0.082 & $0.362^{*}$ & $0.280^{*}$ \\
\hline$\Delta$ Leverage $_{\mathrm{t}}$ & -0.017 & -0.029 & $-0.398^{* *}$ & 0.053 & $0.458^{* * *}$ & $0.406^{* * *}$ & 0.041 & 0.077 & 0.036 \\
\hline
\end{tabular}

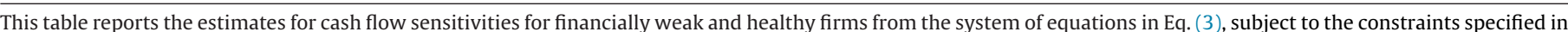

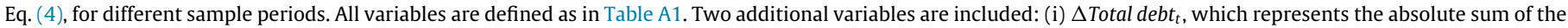

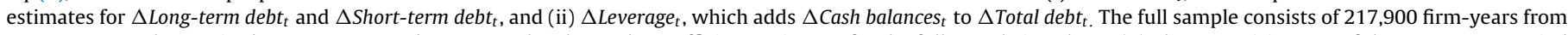

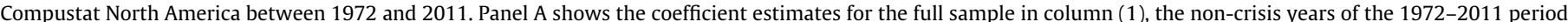

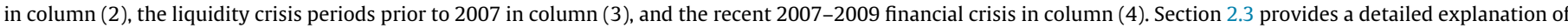

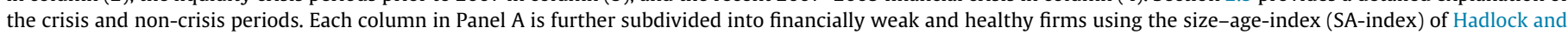

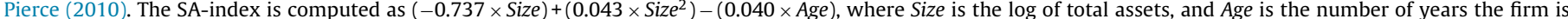

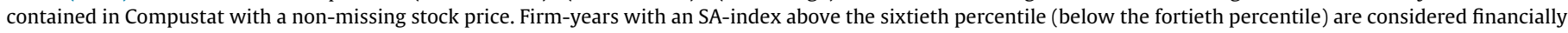

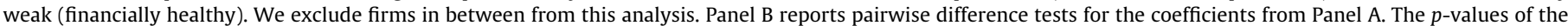

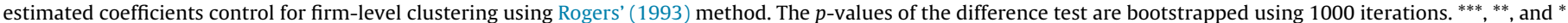
denote significance at the $1 \%, 5 \%$, and $10 \%$ levels, respectively.

results in the context of firms' responses to cash flow shortfalls. To test whether firms react symmetrically to positive and negative cash flow changes, we estimate Eq. (3), subject to the restrictions in Eq. (4), by including an interaction term. The interaction term represents the product of cash flows and a dummy variable that is equal to one when cash flow changes are positive, and zero otherwise. Table 4 shows the results of this symmetry test.

In Panel A, the symmetry tests are conducted for the full sample period, while Panel B shows the results of symmetry tests for the subsample that covers the recent financial crisis. In both panels, column (1) shows firms' reactions to a $\$ 1$ positive cash flow shock. Firms' reaction to a $\$ 1$ shortfall in cash flows is shown in column (2). To correctly interpret the results in column (2) of both panels, the coefficients must be multiplied by -1 . Finally, column (3) tests for differences between positive and negative cash flow shocks.

In both panels, 17 of the 18 estimated coefficients have the expected sign. In Panel A, the unexpected sign is observed in the equity issues equation, when firms experience a positive cash flow shock. The estimate, which is small and statistically insignificant, indicates that firms increase their equity issues in response to positive cash flow shocks. In Panel B, the unexpected sign is in the asset sales equation; firms reduce asset sales when they experience a cash flow shortfall. Most importantly, in eight of the nine equations for the full sample period, firms respond to positive and negative cash flow shocks symmetrically (only equity issues lack symmetry). For example, Panel A shows that firms borrow $\$ 0.437$ of short-term funds when they experience a $\$ 1$ shortfall in cash flows (column (2)). Conversely, when they experience a $\$ 1$ increase in cash flows, they retire $\$ 0.375$ of short-term funds (column (1)); the resulting difference is not statistically different from zero (column (3)).

Panel B of Table 4 shows the results from symmetry tests for the recent financial crisis. The estimates for capital expenditures and cash balances are significantly different in response to positive and negative cash flow shocks. In particular, a $\$ 1$ decline in cash flows leads to a substantial cut (\$0.551) in capital expenditures (column (2)). A symmetric response would require that capital expenditures increase by a similar amount when firms' face a $\$ 1$ increase in cash flows. However, as shown in column (1) of Panel B, a \$1 increase leads to only a $\$ 0.090$ increase in capital expenditures during this crisis. 
Overall, in contrast to Gatchev et al.'s (2010) analysis, the difference tests in column (3) of Panel B indicate that the responses are not symmetric; in fact, six of the nine differences are statistically significant. While firms react symmetrically to innovations in cash flows during the full sample period, this is not the case during the recent financial crisis.

\subsection{Capital market access constraints and crisis severity: the effects of financial health}

We next refine our analysis and estimate the multi-equation model separately for financially weak and healthy firms. Conditional on firms' financial health, Panel A of Table 5 shows the results during normal times, during the three moderate pre-2007 crises, and during the severe financial crisis of 2007-2009. Of the 54 coefficients, 46 have the expected sign. Moreover, 27 of the estimates are statistically significant, and only one of the statistically significant coefficients has the "incorrect" sign (asset sales of financially weak firms during the recent financial crisis).

To analyze the time variation of investment and financing cash flow sensitivities, we first focus on weak firms (columns (1), (3), and (5) in Panel A of Table 5). During normal times, a $\$ 1$ shortfall in cash flows triggers a statistically insignificant $\$ 0.034$ cut in capital expenditures. While a $\$ 1$ shortfall in cash flows generates almost the same reduction during the three moderate liquidity crises (\$0.033), the coefficient is significant at the $1 \%$ level, unlike the estimate for normal times. However, the $\$ 0.554$ cut these firms execute during the recent financial crisis is dramatic. ${ }^{23}$ Even more strikingly, this crisis is the only subsample where the cash flow sensitivity of capital expenditures dominates the sum of the other cash flow sensitivities. Both short- and long-term borrowings of financially weak firms decline monotonically as liquidity conditions become tighter, indicating that issuing debt becomes more difficult as liquidity conditions worsen. For example, while the change in total debt is $\$ 0.952$ in response to a $\$ 1$ decline in cash flows during normal times, this estimate drops sharply to $\$ 0.256$ during the recent financial crisis. At the same time, these firms were able to arrange only a small amount of equity financing (\$0.038). The use of cash balances increases with the severity of the liquidity crisis. During normal times, the conditions for raising funds are favorable enough for financially weak firms that they do not need to draw down their cash balances when they face a shortfall in cash flows. During the moderate crisis periods, these firms use $\$ 0.090$ of internal borrowings; during the 2007-2009 crisis, this amount increases to $\$ 0.181 .{ }^{24}$ In conclusion, both the investment and financing activities of financially weak firms show signs of being curtailed during liquidity crises relative to normal (non-crisis) times. The declines in borrowings and the cuts in capital expenditures are both positively correlated with the severity of the crisis.

Second, the responses of financially healthy firms to a $\$ 1$ shortfall in cash flows over different liquidity conditions are shown in columns (2), (4), and (6) in Panel A of Table 5. Other than a small cut in their capital expenditures during the recent financial crisis, investments (including acquisitions) of financially healthy firms are not materially affected. These firms were able to protect $96 \%$ of their capital budgets from the effects of the severe 2007-2009 crisis. In contrast to financially weak firms, they had

\footnotetext{
23 Campello et al. (2010) provide survey evidence that the recent financial crisis severely affected investments of financially weak firms. They report that $85 \%$ of the responding CFOs of constrained firms affirm that they were forced to forego profitable investment opportunities. In addition, $56 \%$ answered that their firm postponed or even canceled planned investments.

24 This finding is again supported by Campello et al.'s (2010) survey evidence. In their fourth quarter 2008 survey, they also report that financially weak firms used their cash balances heavily during the recent financial crisis.
}

financial flexibility in the form of unused short-term borrowing capacity (\$0.393) and sufficient cash balances (\$0.342). At first glance, the fact that financially healthy firms substitute short-term debt for long-term borrowings during the moderate liquidity crises suggests they faced difficulty in raising funds in long-term debt markets. However, weak firms respond to cash flow shortfalls during these episodes by borrowing almost twice as much long-term debt as healthy firms, which renders this scenario unlikely. Rather, it suggests that the healthy firms' decisions to substitute short- for long-term debt is deliberate (perhaps due to cost considerations). During the recent financial crisis, they borrowed less short-term funds than they did during the earlier crisis periods, and their short maturity debt was essentially at the same level as during normal times. However, even healthy firms were unable to access longterm debt markets during this severe crisis; the small $\$ 0.100$ change is insignificant. ${ }^{25}$

Panel B of Table 5 shows the bootstrap difference tests for the comparison of different pairs of columns from Panel A. The first three columns show the bootstrap difference tests for the traditional measures of capital market frictions, i.e., the cash flow sensitivities of financially weak firms minus the cash flow sensitivities of healthy firms. These tests are conducted during non-crisis times, during the three moderate liquidity crises, and during the recent financial crisis.

The results in column (1) of Panel B show no evidence that firms face any constraints in their investment, financing, or shareholder distribution decisions during non-crisis times. Financially weak firms do not face higher hurdles in raising funds relative to financially healthy firms during normal periods. Both types of firms borrow the same amount of long-term funds ( $\$ 0.483$ and $\$ 0.479$, respectively), but weak firms rely more on short-term borrowings (\$0.469) in financing their cash flow shortfalls than healthy firms (\$0.377). The only difference with (marginal) statistical significance is in the use of cash holdings. ${ }^{26}$ Financially weak firms add to their cash balances ( $\$ 0.056$ ) when they experience a $\$ 1$ cash flow shortfall, while healthy firms reduce their cash holdings (by about the same amount). ${ }^{27}$

The bootstrap difference tests in column (2) of Panel B test for the presence of traditionally defined constraints during the three relatively moderate liquidity crisis periods. While financially weak firms reduce their investments more than healthy firms, both in capital expenditures and acquisitions, the differences are not statistically significant. During the pre-2007 crises, financially weak firms resort to issuing equity, while healthy firms do not; the \$0.095 difference is significant at the $1 \%$ level. The prior literature suggests

\footnotetext{
25 As a further robustness test, we repeat our analysis using Altman's (1968) Zscore as an alternative proxy for financial health. The results (not shown) remain qualitatively the same as in Table 5. For example, the estimate of the investmentcash flow sensitivity for weak firms during the financial crisis is 0.445 (significant at the $5 \%$ level). We further repeat the calculations using the approach of Faulkender and Petersen (2006) and Lemmon and Zender (2010), which uses the probability of a firm to have a public debt rating ("debt capacity") to divide the sample into financially healthy and weak firms. Data is available starting in 1990, and thus we can only compare normal times with the 2007-2009 financial crisis. The results are again qualitatively the same, with an estimate for the investment-cash flow sensitivity of financially weak firms during the recent financial crisis of 0.473 .

${ }^{26}$ Using cash balances does not necessarily imply that a firm is constrained in accessing external capital markets. In the pecking order of Myers and Majluf (1984), firms use internal financing first (which includes cash balances). However, for firms that value financial flexibility, reducing it by using cash balances could mean they are facing difficulties in raising external funds.

27 Neither estimate is significant, but the difference between the financially weak and healthy firms (\$0.113) is significant at the $10 \%$ level. This result suggests that, during non-crisis periods, market conditions for raising capital are favorable such that even weak firms can build up financial flexibility. In contrast, financially healthy firms may be more confident about being able to raise funds when and if the need arises in the future.
} 
that equity issuers tend to be small firms, firms with high-growth opportunities, and low-profitability firms (Fama \& French, 2005; Gatchev et al., 2009). By construction, firms in the financially weak category are smaller because we use Hadlock and Pierce's (2010) size-age index to classify firms, and their average market-to-book ratio is higher (see Panels $B$ and $C$ of Table 1 ). The result that financially weak firms respond to cash flow shortfalls in part by issuing equity is thus consistent with the literature. Healthy firms are able to borrow significantly more short-term debt when they experience cash flow shortfalls than financially weak firms ( $\$ 0.192$ more; significant at the $10 \%$ level). Furthermore, weak firms use more long-term debt ( $\$ 0.171$ more; significant at the $5 \%$ level) than healthy firms. As discussed above, it is likely that financially healthy firms' decisions to borrow less long-term debt are voluntary and are not due to their perceived default risk.

Given the evidence that financially weak firms face hurdles during moderate liquidity crises, we expect that these firms encountered severe obstacles relative to the subsample of healthy firms during the recent financial crisis. In fact, the 2007-2009 crisis was the only period where the investment-cash flow sensitivity of financially weak firms dominates the sum of their financing and distribution sensitivities (see column (5) in Panel A). ${ }^{28}$ Column (3) of Panel B reports bootstrap difference tests for the traditional measures of capital market frictions during this crisis. Most importantly, the difference between the reduction in capital expenditures of financially weak and healthy firms rises sharply to $\$ 0.513$. The results also indicate that the differences in short-term borrowings between the two types of firms increase monotonically with the severity of the crisis, and that financially weak firms could draw down their cash balances significantly less during the 2007-2009 crisis. Compared to financially healthy firms, financially weak firms had limited unused borrowing capacity.

\section{Aggregate capital market access constraints during crisis periods}

The traditional test of Fazzari et al. (1988) considers firms to operate in a constrained environment if financially weak firms have higher investment- and payout-cash flow sensitivities and lower financing-cash flow sensitivities (in absolute values) relative to financially healthy firms (when both experience a $\$ 1$ cash flow shortfall). However, our findings suggest that it is crucial to measure the extent to which both financially weak and healthy firms face more restrictive capital market access constraints during tighter liquidity environments.

For example, consider a case where, during non-crisis years, financially weak and healthy firms respond to a $\$ 1$ shortfall in cash flows by reducing capital expenditures by $\$ 0.03$ and $\$ 0.07$, respectively. Assume further that, during a liquidity crisis, constraints tighten for both types of firms, and that both reduce capital expenditures by a parallel amount, e.g., financially healthy firms cut their capital expenditures by $\$ 0.05$, and financially weak firms by $\$ 0.09$. Based on the conventional approach, we would conclude that, during the liquidity crisis, firms do not face incremental capital market frictions (because the difference between weak and healthy firms remains at \$0.04), but in reality both firms face more stringent constraints during the crisis. Since both firms face higher hurdles in raising funds, the $\$ 0.10$ worth of distortions in the economy increases to $\$ 0.14$ during the liquidity crisis. $^{29}$

\footnotetext{
28 Campello et al. (2010) find that most constrained firms not only cut their capital expenditures in 2008, but also engaged in negative investment activities (asset sales) to fund operations. However, our estimate for weak firms reports a significant decline in asset sales.

${ }^{29}$ While the example is constructed and discussed in the context of investmentcash flow sensitivities, we can provide similar examples for the financing-cash flow
}

To analyze the aggregate distortions to the economy, we first compare the period that covers the relatively moderate pre-2007 liquidity crises with non-crisis years. Starting with financially weak firms, we find statistically significant differences in long- and shortterm borrowings, cash balances, and total debt (column (4) of Panel $B$ in Table 5). When the economy transitions from a normal environment to the pre-2007 liquidity crises regime, financially weak firms experience a $\$ 0.126$ decline in long-term borrowings and a $\$ 0.073$ decline in short-term debt in response to a $\$ 1$ shortfall in cash flows. Therefore, they issue $\$ 0.199$ less total debt when the economy is operating under moderate liquidity crisis conditions relative to non-crisis times. ${ }^{30}$

Analyzing the impact of relatively moderate crises on financially healthy firms (column (7) of Panel B in Table 5), we find that their long-term debt issues decline (by \$0.294), and, as discussed above, they increase their short-term borrowings (by \$0.212) so that the resulting decline in both total debt $(\$ 0.082)$ and leverage $(\$ 0.041)$ is not statistically significant. These findings confirm our results from the traditional tests that financially weak firms experience some degree of capital market access constraints, but moderate liquidity crises have only minimal effects on the financial decisions of healthy firms. In terms of aggregate distortions in the economy, while investments and shareholder distributions are affected minimally, the combined borrowings of financially weak and healthy firms decline by $\$ 0.281$ (the sum of $\$ 0.199$ and $\$ 0.082$ ).

Capital market access constraints during the recent financial crisis were particularly severe for financially weak firms. Columns (5) and (8) of Panel B in Table 5 show tests for differences in cash flow sensitivities during the recent financial crisis and normal times. Weak firms' capital expenditures declined sharply by $\$ 0.520$, and they borrowed less long- and short-term debt $(\$ 0.345$ and $\$ 0.351$ less, respectively). As expected, the adverse effects of severe crises are more severe for financially weak than healthy firms. Financially healthy firms experienced about half the decline in total debt financing (\$0.362 compared to \$0.696). ${ }^{31}$ The aggregate financial market access constraints add up to $\$ 1.058$ for total debt (the sum of $\$ 0.696$ and $\$ 0.362$ ).

For weak firms, the 2007-2009 crisis was severe even compared to the relatively moderate earlier crises. The incremental effects of the 2007-2009 crisis relative to the moderate pre-2007 crises for the subsample of financially weak firms are shown in column (6) of Panel B in Table 5. For capital expenditures, the frictions for financially weak firms are almost as large as the incremental frictions created by the 2007-2009 crisis relative to normal times. All the differences for financing-cash flow sensitivities are significant, and the magnitude of the differences in the estimates for shortand long-term debt is economically important ( $\$ 0.219$ and $\$ 0.278$, respectively). The same analysis is repeated for financially healthy firms in column (9). While these firms were able to borrow roughly the same amount of long-term funds during the recent financial cri-

sensitivities. We note that both the traditional measure of financial constraints and using the sum of the market access constraints faced by financially weak and healthy firms are relative in nature. However, instead of comparing the relative magnitudes of the cash flow sensitivities of financially weak and healthy firms, the latter approach measures the cash flow sensitivities of each financial health-based subsample of firms in one liquidity regime relative to those under another liquidity regime.

${ }^{30}$ The fact that financially weak firms add $\$ 0.056$ to their cash holdings during non-crisis years, while drawing down their cash by $\$ 0.090$ during the pooled period of three moderate crises, implies that the moderate liquidity crises cause the use of this source of financing to increase by $\$ 0.146$. As a result, even though moderate liquidity crises trigger a decline of $\$ 0.199$ in total debt (statistically significant at the $5 \%$ level), the net effect on leverage is only an insignificant $\$ 0.053$ reduction.

31 A comparison of the leverage variable shows that, due to the financial flexibility of healthy firms, the reduction in leverage of financially weak firms sharply exceeds that of healthy firms ( $\$ 0.458$ and $\$ 0.077$, respectively). 
sis as they did during the pre-2007 crises, the composition of their financing sources was different. In particular, they borrowed more short-term funds than during the earlier crises ( $\$ 0.195$ more), and they used internal funds much more heavily (\$0.244 more). These findings confirm that the recent financial crisis was not only severe when compared with non-crisis environments, but also when the earlier relatively moderate crises are used as the benchmark.

\section{Conclusions}

This study examines the extent to which capital market access constraints are related to the severity of liquidity crises. We identify three liquidity-related regimes: (1) the non-liquidity crisis period (normal times), (2) a pooled sample of three relatively moderate liquidity crises prior to 2007, and (3) the recent financial crisis of 2007-2009. We then estimate a multi-equation model for these three environments to test whether the capital market access constraints in the traditional sense (i.e., the differences in cash flow sensitivities between financially weak and financially healthy firms) tighten as liquidity crises become more severe. Our results are consistent with this hypothesis.

The traditional measure of capital market constraints does not show the total costs to firms (and the aggregate economy) by creating distortions in their financial decisions, e.g., by creating underinvestment problems. Therefore, we analyze aggregate capital market access constraints and compare cash flow sensitivities of both financially weak and healthy firms as the economy transitions from one liquidity regime to another. This approach also has the advantage of being able to measure the extent of constraints for the economy as a whole, not merely to assess how much more (less) constrained financially weak firms are than financially healthy firms. The results confirm that financial constraints are positively correlated with the presence of liquidity crises. In particular, it appears that the more severe the liquidity crisis, the more stringent are the aggregate constraints that firms suffer from in the sense of economy-wide underinvestment problems and/or other operational inefficiencies.

\section{Acknowledgments}

We thank Dave Denis, John Duca, Ning Jia, Michael Keefe, Lawrence Kryzanowski, Yom Bui, Vladimir Gatchev, David Matsa, Christian Wolff, seminar participants at Loyola University, Koç University, and Northwestern University, as well as participants at the 2013 Multinational Finance conference in Izmir, the 2013 Australasian Finance and Banking conference in Sydney, the 2013 Auckland Finance Meeting, the 2014 Midwest Finance conference in Orlando, the 2014 Financial Management Asia conference in Tokyo, the 2014 Financial Management Europe conference in Maastricht, and the 2014 World Finance conference in Singapore for helpful comments.

\section{Appendix A.}

See Table A1.

Table A1

Variable definitions.

\begin{tabular}{|c|c|c|c|c|}
\hline & Variable name & Abbreviation & Description & $\begin{array}{l}\text { Construction from Compustat } \\
\text { items }\end{array}$ \\
\hline \multirow[t]{5}{*}{ Source } & Cash flow & $\mathrm{CF}$ & $\begin{array}{l}\text { Internally available cash flow for } \\
\text { investment and financing }\end{array}$ & $\begin{array}{l}\text { oibdp }-(\text { xint }- \text { idit })-(\text { txt }- \text { txdc }) \\
-\triangle N W C\end{array}$ \\
\hline & $\Delta$ Long-term debt & $\Delta \mathrm{LTD}$ & Change in long-term debt & $\Delta$ dltt \\
\hline & $\Delta$ Short-term debt & $\triangle \mathrm{STD}$ & Change in short-term debt & $\Delta$ dlc \\
\hline & Equity issues & EQUISS & Equity issues & sstk \\
\hline & Asset sales & ASALES & Sales of assets and investments & sppe \\
\hline \multirow[t]{5}{*}{ Use } & Share repurchases & $\mathrm{RP}$ & $\begin{array}{l}\text { Purchase of common and preferred } \\
\text { stocks }\end{array}$ & prstkc \\
\hline & Dividends & DIV & Cash dividend & $\mathrm{dv}$ \\
\hline & Capital expenditures & CAPX & Net capital expenditures & capx \\
\hline & Acquisitions & ACQUIS & Acquisitions & aqc \\
\hline & $\Delta$ Cash balances & $\triangle \mathrm{CASH}$ & Change in cash balance & $\Delta$ che \\
\hline \multirow[t]{4}{*}{ Other } & Market-to-book & MB & $\begin{array}{l}\text { Ratio of market value of equity to } \\
\text { book value of equity }\end{array}$ & $\left(\right.$ at $\left.-\operatorname{ceq}^{b}+\operatorname{prcc} \times \operatorname{csho}\right) / a t$ \\
\hline & Firm size & SIZE & Logarithm of total book assets & $\ln ($ at $)$ \\
\hline & $\Delta$ Net working capital & $\triangle \mathrm{NWC}$ & Change in net working capital & (act-che $)-($ lct - dlc $)$ \\
\hline & Research and development expenses & $\mathrm{R} \& \mathrm{D}$ & $\begin{array}{l}\text { All costs incurred related to } \\
\text { development of new products or } \\
\text { services }\end{array}$ & xrd \\
\hline
\end{tabular}

Panel B: variable definitions for the single-equation model ${ }^{c}$

\begin{tabular}{|c|c|c|c|}
\hline Variable name & Abbreviation & Description & Construction from Compustat items \\
\hline Tobin's $q$ & Q & $\begin{array}{l}\text { Market value of assets minus the difference between } \\
\text { the book value of assets and capital stock divided by } \\
\text { capital stock }\end{array}$ & (mkval-(at - ppent)/ppent \\
\hline Market value of assets & MKVAL & $\begin{array}{l}\text { Market value of common stock, plus total liability, plus } \\
\text { preferred stock, minus deferred taxes }\end{array}$ & $(\operatorname{csho} \times \operatorname{prcc})+\mathrm{lt}+$ pstk - txditc \\
\hline Capital expenditures & CAPX & Net capital expenditures & capx \\
\hline Cash flow & CFL & Internal cash flow & $(\mathrm{ib}+\mathrm{dp}) /$ ppent $_{\mathrm{t}-1}$ \\
\hline Capital stock & PPENT & Net property, plant and equipment & ppent \\
\hline
\end{tabular}

a This table summarizes the definitions of the variables contained in the multi-equation model in Eq. (3), and provides the corresponding Compustat items.

b If ceq is missing, either seq or otherwise (at - lt) is used.

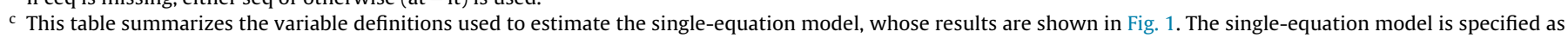
in Fazzari et al. (1988) and Chen and Chen (2012). 


\section{References}

Allayannis, G., \& Mozumdar, A. (2004). The impact of negative cash-flow and influential observations on investment-cash flow sensitivity estimates. Journal of Banking and Finance, 28, 901-930.

Almeida, H., Campello, M., Laranjeira, B., \& Weisbenner, S. (2011). Corporate debt maturity and the real effects of the 2007 credit crisis. Critical Finance Review, 1, 3-58.

Altman, E. (1968). Financial ratios, discriminant analysis and the prediction of corporate bankruptcy. Journal of Finance, 23, 589-609.

Becchetti, L., Castelli, A., \& Hasan, I. (2010). Investment-cash flow sensitivities, credit rationing and financing constraints in small and medium-sized firms. Small Business Economics, 35, 467-497.

Bhagat, S., Moyen, N., \& Suh, I. (2005). Investment and internal funds of distressed firms. Journal of Corporate Finance, 11, 449-472.

Bliss, B. A., Cheng, Y., \& Denis, D. J. (2013). Corporate payout, cash retention, and the supply of credit: Evidence from the credit crisis. Journal of Financial Economics, $115,521-540$.

Bond, S., \& Söderbom, M. (2013). Conditional investment-cash flow sensitivities and financing constraints. Journal of the European Economic Association, 11, 112-136.

Brown, J. R., \& Petersen, B. C. (2009). Why has the investment-cash flow sensitivity declined so sharply? Rising R\&D and equity market developments. Journal of Banking and Finance, 33, 971-984.

Brunnermeier, M. K. (2009). Deciphering the liquidity and credit crunch 2007-2008. Journal of Economic Perspectives, 23, 77-100.

Campello, M., Giambona, E., Graham, J. R., \& Harvey, C. R. (2011). Liquidity management and corporate investment during a financial crisis. Review of Financial Studies, 24, 1944-1979.

Campello, M., Graham, J., \& Harvey, C. (2010). The real effects of financial constraints: Evidence from a financial crisis. Journal of Financial Economics, 97, 470-487.

Chang, X., Dasgupta, S., Wong, G., \& Yao, J. (2014). Cash flow sensitivities and the allocation of internal cash flow. Review of Financial Studies, 27, 3628-3657.

Chen, H., \& Chen, S. (2012). Investment-cash flow sensitivity cannot be a good measure of financial constraints: Evidence from the time series. Journal of Financial Economics, 103, 393-410.

Cleary, S. (1999). The relationship between firm investment and financial status. Journal of Finance, 54, 673-692.

Cleary, S., Povel, P., \& Raith, M. (2007). The U-shaped investment curve: Theory and evidence. Journal of Financial and Quantitative Analysis, 42, 1-39.

Dasgupta, S., Noe, T. H., \& Wang, Z. (2011). Where did all the dollars go? The effect of cash flows on capital and asset structure. Journal of Financial and Quantitative Analysis, 46, 1259-1294.

Duca, J. V. (2013). Did the commercial paper funding facility prevent a Great Depression style money market meltdown? Journal of Financial Stability, 9, 747-758.

Duchin, R., Ozbas, O., \& Sensoy, B. (2010). Costly external finance, corporate investment, and the subprime mortgage credit crisis. Journal of Financial Economics, 97, 418-435.

Erickson, T., \& Whited, T. (2000). Measurement error and the relationship between investment and Q. Journal of Political Economy, 108, 1027-1057.

Fama, E. F., \& French, K. R. (2005). Financing decisions: Who issues stock? Journal of Financial Economics, 76, 549-582.

Faulkender, M., \& Petersen, M. A. (2006). Does the source of capital affect capital structure? Review of Financial Studies, 19, 45-79.

Fazzari, S. M., Hubbard, R. G., \& Petersen, B. C. (1988). Financing constraints and corporate investment. Brookings Paper on Economic Activity, 1988, 141-195.

Francis, B., Hasan, I., Song, L., \& Waisman, M. (2013). Corporate governance and investment-cash flow sensitivity: Evidence from emerging markets. Emerging Markets Review, 15, 57-71.
Gatchev, V. A., Pulvino, T., \& Tarhan, V. (2010). The interdependent and intertemporal nature of financial decisions: An application to cash flow sensitivities. Journal of Finance, 65, 725-763.

Gatchev, V. A., Spindt, P. A., \& Tarhan, V. (2009). How do firms finance their investments? The relative importance of equity issuance and debt contracting costs. Journal of Corporate Finance, 15, 179-195.

Gilchrist, S., \& Himmelberg, C. P. (1995). Evidence in the role of cash flow in reducedform investment equations. Journal of Monetary Economics, 115, 695-705.

Gorton, G., \& Metrick, A. (2012). Securitized banking and the run on repo. Journal of Financial Economics, 104, 425-451.

Graham, J. R., \& Harvey, C. R. (2012). Duke University/CFO Global Business Outlook, U.S. topline tables. Released 6 June 2012. www.cfosurvey.org/pastresults.htm

Hadlock, C. J., \& Pierce, J. R. (2010). New evidence on measuring financial constraints: Moving beyond the KZ index. Review of Financial Studies, 23, 1909-1940.

Hovakimian, G. (2009). Determinants of investment cash flow sensitivity. Financial Management, 38, 181-183.

Ivashina, V., \& Scharfstein, D. (2010). Bank lending during the financial crisis of 2008. Journal of Financial Economics, 97, 319-338.

Kadapakkam, P. R., Kumar, P. C., \& Riddick, L. A. (1998). The impact of cash flow and firm size on investment: The international evidence. Journal of Banking and Finance, 22, 293-320.

Kahle, K. M., \& Stulz, R. M. (2013). Access to capital, investment, and the financial crisis. Journal of Financial Economics, 110, 280-299.

Kaplan, S. N., \& Zingales, L. (1997). Do investment-cash flow sensitivities provide useful measures of financing constraints? Quarterly Journal of Economics, 112, $169-215$.

Lemmon, M. L., \& Zender, J. F. (2010). Debt capacity and tests of capital structure theories. Journal of Financial and Quantitative Analysis, 45, 1161-1187.

Lins, K. V., Strickland, D., \& Zenner, M. (2005). Do non-US firms issue equity on US stock exchanges to relax capital constraints. Journal of Financial and Quantitative Analysis, 40, 109-133.

Love, I. (2003). Financial development and financing constraints: International evidence from the structural model. Review of Financial Studies, 16, 765-791.

McLean, D., \& Zhao, M. (2014). The business cycle, investor sentiment, and costly external finance. Journal of Finance, 69, 137-1409.

Mian, A. R., \& Sufi, A. (2014). What explains the 2007-2009 drop in employment? Econometrica, 82, 2197-2223.

Moyen, N. (2004). Investment-cash flow sensitivities: Constrained versus unconstrained firms. Journal of Finance, 59, 2061-2092.

Myers, S. C., \& Majluf, N. S. (1984). Corporate financing and investment decisions when firms have information that investors do not have. Journal of Financial Economics, 13, 187-221.

Reinhart, C. M., \& Rogoff, K. S. (2011). From financial crash to debt crisis. American Economic Review, 101, 1676-1706.

Roberts, M., \& Whited, T. (2012). Endogeneity in empirical corporate finance. In G. Constantinides, H. Milton, \& R. Stulz (Eds.), Handbook of the economics of finance (vol. 2). Amsterdam, the Netherlands: Elsevier.

Rogers, W.H.(1993). Regression standard errors in clustered samples. Stata Technical Bulletin Reprints, 3, 88-94.

Sanchez, J. M., \& Yurdagul, E. (2013). Why are U. S. firms holding so much cash? An exploration of cross-sectional variation, The Regional Economist 6/2013, Federal Reserve Bank of St. Louis. Review, 95, 293-325.

Spindt, P., \& Tarhan, V. (1980). Liquidity structure adjustment behavior of large money center banks. Journal of Money, Credit and Banking, 12, 198-208. 